\title{
EL ENALTECIMIENTO DE LOS DELITOS PREVISTOS EN EL ART. 510 CP A LA LUZ DE LA ÚLTIMA JURISPRUDENCIA CONSTITUCIONAL
}

\author{
Margarita Roig Torres*
}

Resumen: El artículo 510 CP, en los apartados 1 c) y 2 d), tipifica el enaltecimiento y otras declaraciones de apoyo al genocidio y a los demás delitos cometidos contra grupos o sus miembros por motivos de intolerancia. Para castigar estas conductas se precisa tan solo el favorecimiento de un clima de violencia, hostilidad, odio o discriminación, e incluso en el segundo precepto bastan esas expresiones, de modo que si se promueve ese clima se agrava la pena. Sin embargo, en los últimos años el Tribunal Constitucional ha aplicado la STC 235/2007 al enaltecimiento y justificación de los delitos de terrorismo o de sus autores, del artículo $578.1 \mathrm{CP}$, al entender que constituyen "discurso del odio", al igual que la difusión de ideas que justifiquen el genocidio, analizada en aquella sentencia.

Recibido: julio 2020. Aceptado: octubre 2020

* Catedrática de Derecho Penal. ORCID: 0000-0003-1947-6853.

Facultad de Derecho de la Universidad de Valencia. Dirección Carrer Professor Francisco Tomás I Valiente, 4, 46022. Email: margarita.roig@ uv.es. 
En consecuencia, requiere que esas manifestaciones favorables al terrorismo creen cierto peligro no previsto en la norma. Y, a mi modo de ver, esta exigencia se ha de tener en cuenta al interpretar aquellos preceptos del artículo $510 \mathrm{CP}$.

Palabras clave: enaltecimiento; discurso del odio; delitos de odio; artículo $510 \mathrm{CP}$; libertad de expresión.

THE EXALTATION OF THE CRIMES REGULATED IN ART. 510 CP IN VIEW OF THE LAST CONSTITUTIONAL JURISPRUDENCE

\begin{abstract}
Article $510 \mathrm{CP}$, in sections $1 \mathrm{c}$ ) and $2 \mathrm{~d}$ ), typifies exaltation and other declarations of support for genocide and other crimes committed against groups or their members for reasons of intolerance. To punish these behaviors, it is only necessary to promote a climate of violence, hostility, hatred or discrimination, and even in the second precept those expressions are enough, so that if that climate is promoted, the penalty is increased. However, in recent years the Constitutional Court has applied STC 235/2007 to the exaltation and justification of terrorist offenses or their authors, of article $578.1 \mathrm{CP}$, on the understanding that they constitute "hate speech", as well as the dissemination of ideas that justify genocide, analyzed in that sentence. Consequently, it requires that such pro-terrorism expressions create a certain danger not predicted in the standard. And, in my opinion, this requirement must be taken into account when interpreting those provisions of article $510 \mathrm{CP}$.

Keywords: exaltation; hate speech; hate crimes; article $510 \mathrm{CP}$; freedom of speech.
\end{abstract}

\title{
I. Introducción
}

En el Código penal se castigan diversas conductas que, a juicio del legislador, alientan o favorecen la comisión de delitos, a través de su enaltecimiento o del ensalzamiento de sus autores. A la cabeza de esa normativa se encuentra la apología regulada en el artículo $18 \mathrm{CP}$. Este precepto no genera reparos desde el prisma de la libertad de expresión, 
puesto que en el Código vigente se requiere en todo caso una incitación directa a realizar un delito. Una cuestión que en un principio se suscitó fue si bastaba instar a delinquir, o si era necesario hacerlo a un ilícito específico. Pero la doctrina ${ }^{1}$ y la jurisprudencia ${ }^{2}$, a partir del tenor de esa disposición llegó a una solución unánime, manteniendo de modo coherente el segundo criterio.

Sin embargo, junto a esa previsión general, se castigan otras formas de enaltecimiento, que a mi juicio sí plantean serias dudas desde el principio de proporcionalidad y de los derechos a la libertad ideológica (art.16.1 CE) y a la libertad de expresión (art. 20.1 CE). El tipo tradicional de esta índole es el regulado en el artículo 578.1 CP que sanciona, con una pena de prisión de uno a tres años y multa de doce a dieciocho meses, el enaltecimiento y la justificación públicos de los delitos de terrorismo, o de quienes hayan participado en su

1 CAMPOS MORENO, J.C.: "Actos preparatorios punibles", en Cuadernos de Derecho Judicial, vol. 39, 1994, pp. 9 y 10; CORCOY BIDASOLO, M./MIR PUIG, S.: Comentarios al Código penal. Reforma LO 1/2015 y LO 2/2015, Tirant lo Blanch, Valencia, 2015, p. 102; CÓRDOBA RODA, J./GARCÍA ARÁN, M.: Comentarios al Código penal. Parte general, Marcial Pons, Madrid, 2011, p. 143; CUERDA ARNAU, M.L.: "El nuevo delito político: apología, enaltecimiento y opinión", en Estudios de Derecho Judicial, no 128, 2007, p. 4; MAQUEDA ABREU, M.L.: "Algunas reflexiones críticas acerca de la punición de la apología", en Revista del Poder Judicial, n 9, 1988, p. 7; MORALES PRATS, F., en QUINTERO OLIVARES, G. (Dir.)/MORALES PRATS, F. (Coord.): Comentarios al Código penal español, Tomo I, Aranzadi, Pamplona, 2016, p. 182; ORTS BERENGUER, E.: "Consideraciones sobre la fase interna y los actos preparatorios del delito", en Cuadernos de Politica Criminal, $\mathrm{n}^{\circ} 18,1982$, p. 507; ORTS BERENGUER, E./GONZÁLEZ CUSSAC, J.L.: Compendio de Derecho penal. Parte general, Tirant lo Blanch, Valencia, 2019, pp. 274 y 276; REBOLLO VARGAS, R: La provocación y la apología en el nuevo Código penal, Tirant lo Blanch, Valencia, 1997, p. 89; y, VIVES ANTÓN, T.S., en VIVES ANTÓN, T.S. (Coord.): Comentarios al Código penal de 1995, vol. I, Tirant lo Blanch, Valencia, 1996, p. 106.

2 Pueden verse, por ejemplo, las SSTS 948/2016, de 15 de diciembre (F.J.4), y, 396/2018, de 9 de febrero (F.J.Único). 
ejecución, y que no requiere expresamente una incitación, ni directa ni indirecta, a realizar esos actos.

Pero el artículo 510 CP prevé también varias fórmulas de ese estilo. En el apartado 1 c), castiga, con una pena de prisión de uno a cuatro años y multa de seis a doce meses, a quienes "públicamente nieguen, trivialicen gravemente o enaltezcan los delitos de genocidio, de lesa humanidad o contra las personas y bienes protegidos en caso de conflicto armado, o enaltezcan a sus autores, cuando se hubieran cometido contra un grupo o una parte del mismo, o contra una persona determinada por razón de su pertenencia al mismo", por los motivos de intolerancia que se indican ${ }^{3}$. El tipo requiere que, "de este modo se promueva o favorezca un clima de violencia, hostilidad, odio o discriminación contra los mismos".

Después, en el apartado 2 b), establece una pena de prisión de seis meses a dos años y multa de seis a doce meses, a "quienes enaltezcan o justifiquen por cualquier medio de expresión pública o de difusión los delitos que hubieran sido cometidos contra un grupo, una parte del mismo, o contra una persona determinada por razón de su pertenencia a aquél”, por las mismas razones sectarias. En este caso no se precisa el favorecimiento del clima descrito en el apartado anterior, pues si se promueve se aplica el tipo agravado del

3 Artículo 510: 1. "Serán castigados con una pena de prisión de uno a cuatro años y multa de seis a doce meses:... c) -Quienes- Públicamente nieguen, trivialicen gravemente o enaltezcan los delitos de genocidio, de lesa humanidad o contra las personas y bienes protegidos en caso de conflicto armado, o enaltezcan a sus autores, cuando se hubieran cometido contra un grupo o una parte del mismo, o contra una persona determinada por razón de su pertenencia al mismo, por motivos racistas, antisemitas u otros referentes a la ideología, religión o creencias, la situación familiar o la pertenencia de sus miembros a una etnia, raza o nación, su origen nacional, su sexo, orientación o identidad sexual, por razones de género, enfermedad o discapacidad, cuando de este modo se promueva o favorezca un clima de violencia, hostilidad, odio o discriminación contra los mismos". 
párrafo segundo, que señala penas de uno a cuatro años de prisión y multa de seis a doce meses.

El Tribunal Constitucional ha avalado la punición excepcional de la justificación del genocidio, y del enaltecimiento y justificación del terrorismo, por el carácter odioso y peligroso de esos delitos para la esencia misma de la sociedad, estableciendo una similitud entre ambas figuras. Ahora bien, ha fijado presupuestos para que esas expresiones sean conformes a los derechos apuntados, que no se recogen en los preceptos anteriores. Precisamente, en los últimos años ha dictado algunas resoluciones sobre el enaltecimiento y justificación del terrorismo del artículo $578.1 \mathrm{CP}$, que a mi modo de ver se han de tener presentes al interpretar esos tipos del artículo $510 \mathrm{CP}$, que no han sido sometidos, en cambio, a su consideración.

Por lo tanto, los elementos de juicio para valorar esas normas (art. 510.1 c y 2 b CP) son, la STC -Pleno-235/2007, de 7 de noviembre -en adelante, STC 235/2007-, en la que se apoyó el legislador en la reforma del artículo $510 \mathrm{CP}$ operada por la LO 1/2015, de 30 de marzo, pero también las resoluciones posteriores sobre la libertad de expresión, y, en particular, las que atañen al enaltecimiento del terrorismo. Además, se ha de observar la Decisión Marco 2008/913/JAI, relativa a la lucha contra determinadas formas y manifestaciones de racismo y xenofobia mediante el Derecho penal, que impulsó también la modificación de aquel precepto.

Esta Decisión Marco obligaba a los Estados miembros a castigar, como "Delitos de carácter racista o xenófobo", la apología pública, la negación o la trivialización flagrante de los crímenes de genocidio, crímenes contra la humanidad y crímenes de guerra, dirigida contra un grupo de personas o un miembro de tal grupo definido en relación con la raza, el color, la religión, la ascendencia o el origen nacional o étnico cuando las conductas puedan incitar a la violencia o al odio contra tal grupo o un miembro del mismo. No obstante, disponía que los Estados miembros podrán optar por castigar 
únicamente las conductas que o bien se lleven a cabo de forma que puedan dar lugar a perturbaciones del orden público o que sean amenazadoras, abusivas o insultantes ${ }^{4}$.

En cambio, no preveía la sanción del enaltecimiento o justificación de cualesquiera delitos cometidos contra esos grupos o sus miembros, como contempla el artículo 510 , apartado 2 b) CP. De manera que en este precepto se añadían estas acciones que no recogía la norma europea $y$, además, se prescindía del elemento consistente en la creación de un clima de violencia, hostilidad, odio o discriminación, que precisa el artículo 510, apartado $1 \mathrm{c}$ ) CP para castigar el enaltecimiento de delitos tan graves como los de genocidio, lesa humanidad o contra las personas y bienes protegidos en caso de conflicto armado.

Por consiguiente, es importante comprobar si estos delitos (art. 510.1 c y 2 b CP) se acomodan a las directrices fijadas por el Tribunal Constitucional para limitar el derecho fundamental a la libertad de expresión (art. 20.1 CE), en los casos de "discurso del odio", es decir, cuando las declaraciones están motivadas por razones de intolerancia. A su vez, en sus resoluciones se advierte una marcada influencia de la jurisprudencia del TEDH, que conviene tener en cuenta.

En este sentido, hay que apuntar que ambos tribunales han ampliado el contenido del "discurso del odio", que nació para designar las expresiones contra grupos o sus miembros, por motivos racistas o xenófobos u otras razones sectarias, y lo aplican al enaltecimiento y justificación del terrorismo. Esta postura se mantiene con carácter general en la jurisprudencia, al entender que detrás de este delito hay una actitud de desprecio hacia las víctimas por causas ideológicas, políticas o religiosas, que es equiparable al móvil discriminador que provoca aquellas conductas 5 . Se argumenta que el dis-

4 Artículo 1, apartado 2.

5 BERNAL DEL CASTILLO, J.: "El enaltecimiento del terrorismo y la humillación a sus víctimas como formas del «discurso del odio»", en 
curso del terrorismo es una manifestación de la intolerancia más absoluta, en tanto se basa en el exterminio del disidente ${ }^{6}$. De manera que, en la práctica judicial se incluyen en el "discurso del odio", tanto las expresiones tipificadas en el artículo $510 \mathrm{CP}$, como las sancionadas en los artículos 578 y $579 \mathrm{CP}^{7}$. Esta asimilación confirma que las declaraciones del Tribunal Constitucional sobre estas disposiciones influyen en la interpretación de aquel precepto.

Revista de Derecho Penal y Criminología, $\mathrm{n}^{\circ}$ 16, 2018, p. 29; DOPICO, J.: "Desconciertos de Brandemburgo", Límites a la libertad de expresión, en Boletín Juezas y Jueces para la Democracia, mayo de 2018, pp. 15 y ss; FUENTES OSORIO, J.L: "El odio como delito", en Revista Electrónica de Derecho Penal y Criminología, 19-27, 2017, p. 4, cita 17; GALÁN MUÑOZ, A.: "El delito de enaltecimiento terrorista. ¿Elemento de lucha contra el peligroso discurso del odio terrorista o mecanismo represor de repudiables mensajes de raperos, twitteros y titiriteros?", en Estudios Penales y Criminológicos, vol. XXXVII, 2018, pp. 245 y ss; MOLINA BLÁZQUEZ, M.C.: "Valoración crítica de la Circular 7/2019 de la Fiscalía General del Estado sobre las pautas para interpretar los delitos de odio del art. 510 del Código penal”, en GUZMÁN ORDAZ, R. (Coord.)/GORJÓN BARRANCO, M.C. (Dir.): Políticas públicas en defensa de la inclusión, la diversidad y el género, Universidad de Salamanca, 2020, p. 3. (Disponible en: https://repositorio.comillas.edu/xmlui/handle/11531/45031); MORENO HUERTA, J. D.: "Análisis del nuevo delito de adoctrinamiento del artículo 575.2 del Código penal incorporado con la Ley Orgánica 2/2015 (1), en Anuario de Derecho Penal y Ciencias Penales, vol. LXX, 2017, p. 335; RODRÍGUEZ PADRÓN, C.: "Delitos de odio", en Cuadernos Digitales de Formación, Consejo General del Poder Judicial, n 39, 2018, p. 2; SÁEZ VALCÁRCEL, J.R.: "Apología del terrorismo, libertad de expresión y libertad de creación artística. La criminalización del arte, la ficción y la caricatura", en Cuadernos Digitales de Formación, Consejo General del Poder Judicial, n 40, 2019, pp. 4 y ss; y, VALLS PRIETO, J., en MORILLAS CUEVA (Dir.): Estudios sobre el Código penal reformado, Dykinson, Madrid, 2015, p. 865.

6 Véase, la STC 112/2016, de 20 de junio.

7 Especialmente críticos con esta visión se muestran, CORRECHER MIRA, J.: “¿Fin de la broma? El caso Strawberry y el canon constitucional sobre libertad de expresión aplicado al enaltecimiento del terrorismo (1)", en Diario La Ley, n 9600, 24 de marzo de 2020, p. 6; GÓMEZ MARTÍN, V.: Delitos de discriminación y discurso del odio punible. Nuevo escenario en España tras la LO 1/2015, Juruá Editorial, Portugal, 2019, p. 114; y, LAURENZO COPELLO, P.: "La manipulación de los 


\section{EI «discurso del odio» en la jurisprudencia del TEDH}

\section{Doctrina general sobre el «discurso del odio»}

Es importante precisar que el concepto de "discurso del odio" que recoge la Corte europea en su jurisprudencia no está destinado solo al orden penal. Se trata de un presupuesto que permite a los Estados miembros someter la libertad de expresión garantizada en el artículo 10, apartado 1, del CEDH, a "formalidades, condiciones, restricciones o sanciones", si se cumplen los presupuestos establecidos en el apartado 2: que la limitación esté prevista por la ley nacional, que responda a un fin legítimo de los recogidos en el la propia norma y que sea necesaria en una sociedad democrática $^{8}$. Entre esos fines, se encuentran la seguridad nacional, la integridad territorial y la prevención del delito, pero también otros como la moral o la reputación. Como es lógico, esto no significa que quepa aplicar sanciones penales para tutelar estos bienes. El TEDH comprueba en cada caso si la medida adoptada por las autoridades estatales es proporcionada

delitos de odio", en PORTILLA CONTRERAS, G./VELÁSQUEZ VELÁSQUEZ, F. (Dir.)/POMARES CINTAS, E./FUENTES OSORIO, J.L. (Coord.): Un juez para la democracia. Libro Homenaje a Perfecto Agustín Andrés Ibáñez, Dykinson, Madrid, 2020, p. 453.

8 Artículo 10 -Libertad de expresión-:

"1. Toda persona tiene derecho a la libertad de expresión. Este derecho comprende la libertad de opinión y la libertad de recibir o de comunicar informaciones o ideas sin que pueda haber injerencia de autoridades públicas y sin consideración de fronteras. El presente artículo no impide que los Estados sometan a las empresas de radiodifusión, de cinematografía o de televisión a un régimen de autorización previa.

2. El ejercicio de estas libertades, que entrañan deberes y responsabilidades, podrá ser sometido a ciertas formalidades, condiciones, restricciones o sanciones, previstas por la ley, que constituyan medidas necesarias, en una sociedad democrática, para la seguridad nacional, la integridad territorial o la seguridad pública, la defensa del orden y la prevención del delito, la protección de la salud o de la moral, la protección de la reputación o de los derechos ajenos, para impedir la divulgación de informaciones confidenciales o para garantizar la autoridad y la imparcialidad del poder judicial". 
al objetivo legítimo perseguido. De forma que, solo cuando una expresión afecta a otros derechos esenciales del $\mathrm{CEDH}$ admite la intervención penal. Esa ponderación, además, la hace atendiendo al contexto y a las circunstancias concretas de cada caso? .

Pues bien, para definirlo la Corte se basa en la Recomendación No R (97) 20 del Comité de Ministros del Consejo de Europa sobre el "discurso del odio", adoptada el 30 de octubre de $1997^{10}$. En ella se dice que esta figura "abarca todas las formas de expresión que propagan, incitan, promueven o justifican el odio racial, la xenofobia, el antisemitismo u otras formas de odio basado en la intolerancia”.

Sin embargo, partiendo de esta noción genérica ha utilizado la expresión "discurso del odio" con un sentido más o menos estricto, según el suceso que estuviese enjuiciando y ha restringido la sanción penal a los supuestos más graves.

Aquí me limitaré a apuntar algunas resoluciones representativas que, a mi juicio, sintetizan la postura de la Corte, pero sin profundizar en su amplia jurisprudencia sobre el tema, puesto que la trato con mayor extensión en otro trabajo $^{11}$. No obstante, me referiré a algunas sentencias novedosas en materia de terrorismo, en tanto me parecen relevantes de cara a las consideraciones que después realizaré sobre el enaltecimiento del terrorismo.

9 Pueden verse, los casos Hans Burkhard Nix v. Germany, de 13 de marzo de 2018. (Disponible: https://hudoc.echr.coe.int/eng\#\{“itemid":[“001-182241"]\}), y, Stern Taulats y Roura Capellera c. España, de 13 de marzo de 2018. (Disponible en: https://hudoc.echr.coe.int/spa\#\{\%22itemid $\% 22:[\% 22001-182461 \% 22]\})$.

10 (Disponible en: https://rm.coe.int/1680505d5b).

11 ROIG TORRES, M.: Delimitación entre libertad de expresión y «discurso del odio». Postura del TEDH, del Tribunal Constitucional español y del Tribunal Constitucional alemán, Tirant lo Blanch, Valencia, 2020, pp. 27 y ss. 
Así, en la sentencia del caso Erdogdu and Ince v. Turkey de 8 de julio de $1999^{12}$, el TEDH incluye algunas frases en las que parece requerir incitación a la violencia para afirmar el "discurso del odio". En concreto, señala que, "donde las ideas incitan a la violencia contra un individuo, un cargo público o un sector de la población, la autoridad estatal dispone de un amplio margen para limitar la libertad de expresión". El Tribunal debía resolver si los recurrentes habían inducido a la violencia al publicar una entrevista a un sociólogo en la que hablaba del Partido de los Trabajadores del Kurdistán (PKK), incluido en la lista de organizaciones terroristas de la Unión Europea. A su juicio, el texto no contenía ningún pasaje que instara a la violencia, por lo que la sanción vulneró la libertad de expresión de los solicitantes. No obstante, afirma que los profesionales de la información deben tener precaución al publicar las opiniones de quienes recurren a la violencia contra el Estado, para evitar que los medios de comunicación sean un vehículo para la difusión del "discurso de odio" y la promoción de la violencia. En realidad, la Corte separa estos dos elementos, pero se centra en el segundo porque fue el que motivó el fallo condenatorio.

En cambio, en el caso Fêret v. Belgium de 16 de Julio de $2009^{13}$, el TEDH declara que la incitación al odio no necesariamente requiere un acto de violencia $u$ otro acto delictivo. Los abusos consistentes en injuriar, ridiculizar o difamar a partes de la población y grupos específicos o la incitación a la discriminación, son suficientes para que las autoridades den prioridad a la lucha contra las expresiones racistas y que socavan la dignidad o la seguridad de tales grupos sobre la libertad de expresión. El solicitante fue condenado porque durante una campaña electoral distribuyó publicidad de carácter xenófobo. La Corte argumenta que los discursos políticos que inciten al odio basado en el prejuicio religioso, étnico o cultural representan una amenaza para la paz social.

12 (Disponible en: https://www.legal-tools.org/doc/e3d28c/pdf/).

13 (Disponible en: https://hudoc.echr.coe.int/eng\#\{\%22itemid $\% 22:[\% 22001-93626 \% 22]\})$. 
Así pues, la incitación al odio no se prohíbe por el sentimiento que puede provocar, sino que ha de conllevar una ofensa al honor o un riesgo de desencadenar acciones concretas que alteren la paz social.

Más tarde, en el caso Vejdeland and others v. Sweden, de 9 de febrero de $2012^{14}$, el TEDH declaró que incitar al odio no implica una llamada a un acto de violencia u otros actos delictivos, sino que también los ataques a personas cometidos mediante insultos, o que ridiculizan o calumnian a grupos específicos de la población son "discurso del odio". De forma que, incluye en este concepto las ofensas al honor.

En resumen, según las declaraciones del TEDH el "discurso del odio" comprende las expresiones que incitan, promueven, justifican o difunden el odio, la hostilidad, la violencia o la discriminación contra un grupo o sus miembros, o atentan contra su honor, por motivos de intolerancia. Además, declara que lo integra también la negación de hechos históricos refutados, particularmente el Holocausto judío, por cuanto, a su juicio, esa negación entraña una difamación para las víctimas ${ }^{15}$.

Ahora bien, para estimar justificada una sanción penal requiere que la conducta afecte al honor, o incite a realizar actos violentos o delictivos ${ }^{16}$.

14 (Disponible en: file:///E:/GIR/001-109046.pdf).

15 Caso Garaudy v. France, de 24 de junio de 2003. (Disponible en: http:// www.proyectos.cchs.csic.es/transitionaljustice/sites/default/files/maps/ info/case-law/GARAUDY\%20v.\%20FRANCE.pdf), caso Chauvy and others v. France, de 29 de junio de 2004. (Disponible en: http://www. proyectos.cchs.csic.es/transitionaljustice/sites/default/files/maps/info/case-law/CASE $\% 20$ OF $\% 20$ CHAUVY $\% 20$ AND $\% 20$ OTHERS $\% 20 v . \% 20$ FRANCE.pdf), y, caso M. Bala M. Bala v. France, de 20 de octubre de 2015. (Disponible en: https://www.echr.coe.int/Documents/FS_Hate_ speech_ENG.pdf).

16 Ampliamente, ROIG TORRES, M.: Delimitación entre libertad de expresión y «discurso del odio»..., cit., pp. 42 y ss. 
Nótese, pues, que no respalda las condenas que simplemente fomentan o favorecen el odio. Desde mi punto de vista, esta lectura es acorde con el derecho a la libertad de expresión del artículo 10.1 CEDH, dado que propiciar un sentimiento no es una conducta que afecte gravemente a la convivencia externa y, por lo tanto, debe quedar fuera nuestro Derecho penal, regido por el principio de intervención mínima.

\section{La alabanza o justificación del terrorismo como «discurso del odio»}

El TEDH ha utilizado la denominación "discurso del odio" para referirse a las declaraciones que apoyan o justifican el terrorismo.

En nuestra jurisprudencia ${ }^{17}$ se cita como base de esa doctrina el caso Sürek v. Turkey, de 8 de julio de $1999^{18}$. El Tribunal europeo refrendó la condena por difundir propaganda separatista, impuesta al titular de una revista en la que se publicaron cartas de lectores censurando los ataques del ejército turco en el Kurdistán. Dice la Corte que, "el contenido de las cartas debe considerarse como capaz de incitar a una mayor violencia en la región inculcando un odio profundamente arraigado e irracional contra los que se consideran responsables de las presuntas atrocidades". Por lo tanto, "lo que está en cuestión en el presente caso es el «discurso de odio» y la glorificación de la violencia". El "discurso del odio" aludía a declaraciones capaces de alentar la violencia motivada por el odio reinante en la región.

En el caso Gündüz v. Turkey, de 14 de junio de $2004^{19}$, estimó el recurso de un líder de la comunidad islámica que fue condenado por incitación al odio y la hostilidad, porque durante un debate en televisión se pronunció a favor de la

17 Véase, la STC 112/2016, de 20 de junio.

18 (Disponible en: https://www.legal-tools.org/doc/e3d28c/pdf/).

19 (Disponible en: https://www.legal-tools.org/doc/74a144/pdf/). 
Sharia, afirmando que los valores de la democracia eran incompatibles con el Islam. La Corte juzga innecesaria la sanción penal para unas declaraciones que eran "discurso del odio", en tanto fomentaban el odio y la hostilidad frente a quienes no profesaban la ley islámica, pero no instaban a la violencia.

Igualmente, en el caso Bahçeci et Turan c. Turquie, de 16 de junio de $2009^{20}$, considera inadecuada la pena impuesta a los solicitantes por enviar un mensaje de móvil con la imagen de un líder del PKK, acompañada de una frase de alabanza, acto que fue calificado por los tribunales nacionales como divulgación de propaganda separatista. La Corte argumenta que el mensaje no reclamaba el uso de la violencia, la resistencia armada, ni el levantamiento y tampoco era "discurso del odio". Al igual que en algunas sentencias anteriores, alude por separado a este concepto para dar cabida a otras expresiones, pero analiza si hubo incitación a la violencia como manifestación extrema de ese discurso que sirviera de fundamento a la sanción penal21 ${ }^{21}$.

Por lo tanto, el contraste que parece advertirse entre esta sentencia, que rechaza la pena impuesta a los solicitantes por distribución de propaganda separatista, y la del caso Sürek v. Turkey, que por el contrario avala la condena por publicar textos de este carácter, se debe, a mi modo de ver, a que en este asunto las cartas publicadas inducían a la violencia, mientras en el caso Bahçeci et Turan c. Turquie el mensaje no conllevaba esa incitación.

20 (Disponible en: https://hudoc.echr.coe.int/eng\#\{“itemid":[“001-93006”]\}).

21 Pueden verse los casos, Emir c. Turquie, de 3 de agosto de 2008. (Disponible en: https://hudoc.echr.coe.int/eng\#\{“itemid":[“001-80452"]\}, Sürek v. Turkey, de 8 de julio de 1999. (Disponible en: https://www.legaltools.org/doc/e3d28c/pdf/), y, Gerger v. Turkey, de 8 de julio de 1999. (Disponible en: https://hudoc.echr.coe.int/eng\#\{“fulltext":[“gerger"],"s ort":["EMPTY"],"documentcollectionid2":["GRANDCHAMBER"," CHAMBER”],"itemid”:[“001-58272”]\}. 
Lo importante, pues, es que en estas resoluciones la Corte califica las declaraciones de apoyo al terrorismo como "discurso del odio", pero solo considera fundada la imposición de una pena cuando promueven la violencia.

En realidad, en la jurisprudencia del TEDH se reputa necesaria la intervención penal cuando las expresiones relacionadas con el terrorismo supongan un riesgo para la seguridad nacional, la integridad territorial o la seguridad pública, la defensa del orden o la prevención del delito (art.10.2 $\mathrm{CEDH})$. Y esto se traduce en la exigencia de que alienten a la violencia ${ }^{22}$.

En suma, para que el "discurso del odio" legitime la intervención punitiva el TEDH precisa que las expresiones lesionen el honor, o inciten a la violencia o a cometer hechos delictivos y, específicamente, en el ámbito del terrorismo que conlleven este efecto.

22 Así, el caso Zana v. Turkey, de 25 de noviembre de 1997. (Disponible en: https://hudoc.echr.coe.int/eng\#\{“fulltext":[“Zana”],"docum entcollectionid2":[“GRANDCHAMBER","CHAMBER"],"item id":[“001-58115”]), el caso Halis Doğan c. Turquei, de 7 de febrero de 2006. (Disponible en: https://hudoc.echr.coe.int/eng\#\{"fulltext":["AFFAIRE HALIS DOĞAN c. TURQUIE"],"documentcollectionid2":[“GRAN DCHAMBER","CHAMBER"],"itemid":[“001-72320”]\}), el caso Leroy c. France, de 2 de octubre de 2008. (Disponible en: https://hudoc. echr.coe.int/eng\#\{“itemid":[“001-88657”]\}), el caso Belkacem v. Belgium, de 27 de junio de 2017. (Disponible en: https://www.echr.coe.int/ Documents/FS_Hate_speech_ENG.pdf), y, el caso Roj TV A/S v. Denmark, de 24 de mayo de 2018. (Disponible en: https://hudoc.echr.coe. int $/ .$. /pdf?...Decision $\% 20$ Roj $\% 20$ TV $\% 20$ A._S $\% 20 v . \% 20$ Denmark $\% 20$ - $\% 20$ applicant $\% 20$ company $\% 20$ may $\% 20$ not $\% 20$ benefit $\% 20$ from $\% 20$ Art. $\% 2010 \% 20$ by $\% 20$ virtue $\% 20$ of $\% 20$ Art. $\% 2017$.pdf). 


\section{La doctrina del Tribunal Constitucional sobre la libertad de expresión y el «discurso del odio»}

\section{Introducción}

El Tribunal Constitucional acuñó su postura sobre el contenido y los límites del derecho fundamental a la libertad de expresión del artículo 20.1 CE en las SSTC 6/1981, de 16 de marzo y 12/1982, de 31 de marzo. En ellas, destacó que la libertad de expresión e información no sólo protege un interés individual, sino que garantiza una institución política fundamental, la opinión pública libre, esencial en nuestro Estado democrático ${ }^{23}$. Por eso, cuando su ejercicio se refiere a cuestiones de interés general ${ }^{24}$, le atribuye un carácter preferente sobre los demás derechos fundamentales ${ }^{25}$. Esto supone que para restringirlo se ha de hacer una rigurosa ponderación de los derechos implicados, partiendo de esa jerarquía institucional ${ }^{26}$.

23 SSTC 6/1981, de 16 de marzo (F.J.3), y, 12/1982, de 31 de marzo (F.J.3). En el mismo sentido, las SSTC 104/1986, de 17 de julio (F.J.5), 159/1986, de 16 de diciembre (F.J.6), 20/1990, de 15 de febrero (F.J.4), y, 214/1991, de 11 de noviembre (F.J.6).

24 STC 214/1991, de 11 de noviembre (F.J.6).

25 STC 159/1986, de 16 de diciembre (F.J.6).

$26 \mathrm{Al}$ respecto, CARBONELL MATEU, J.C.: "Las libertades de información y expresión como objeto de tutela y como límites a la actuación del Derecho penal", en Estudios Penales y Criminológicos, $\mathrm{n}^{\circ} 18$, 1994-1995, p. 16. (Disponible en: https://dialnet.unirioja.es/servlet/ articulo?codigo=2104173); CUERDA ARNAU, M.L.: "Libertad de expresión y crítica política a la luz de la jurisprudencia del TEDH", en Teoría \& Derecho: Revista de Pensamiento Jurídico, n $^{\circ}$ 13, 2013, pp. 221 y ss; HORMAZÁBAL MALAREÉ, H.: "Soberanía y responsabilidad internacional”, en CARBONELL, J.C./GONZÁLEZ CUSSAC, J.L./ ORTS BERENGUER, E. (Dir.)/CUERDA ARNAU, M.L. (Coord.): Constitución, derechos fundamentales y sistema penal, Tomo II, Tirant lo Blanch, Valencia, 2009, pp. 999 y ss; VIVES ANTÓN, T.S.: Libertad de prensa y responsabilidad criminal. (La regulación de la autoría en los delitos cometidos por medio de imprenta), vol. 14, Publicaciones del Instituto de Criminología de la Universidad Complutense de Madrid, 1977, pp. 12 y ss; y, VIVES ANTÓN, T.S.: La libertad como pretexto, Tirant lo Blanch, Valencia, 1995, pp. 368 y 369. 
No obstante, como todos los derechos fundamentales está sujeto a límites. Y, en lo que aquí interesa, ha declarado que el artículo 20.1 CE no ampara las expresiones discriminatorias, puesto que son contrarias a la dignidad humana (art. 10 C.E. $)^{27}$.

Eso explica la tipificación de los delitos regulados en los artículos 510 y 510 bis CP. En la redacción de estos preceptos fue decisiva la STC 235/2007, como expuso el legislador en la LO 1/2015, donde argumentó que la modificación de esas normas respondía a la necesidad de acomodarlas a la interpretación efectuada en dicha sentencia, además de transponer la Decisión Marco 2008/913/JAI.

De todos modos, ya anticipo que, a mi juicio, algunos tipos de enaltecimiento y apoyo de ciertos delitos regulados en el artículo $510 \mathrm{CP}$, no cumplen los requisitos fijados en la STC 235/2007 para fundar la exclusión del derecho a la libertad de expresión. Además, en los últimos años el Tribunal Constitucional ha aplicado esa sentencia a los delitos de enaltecimiento y justificación del terrorismo del artículo 578.1 CP. Estas resoluciones evidencian claramente las deficiencias de las citadas figuras del artículo 510 CP.

\section{La STC -Pleno- 235/2007, de 7 octubre}

Como es sabido, en la STC 235/2007 el Tribunal declaró inconstitucional el tipo consistente en la difusión de ideas o doctrinas que nieguen los delitos de genocidio, previsto en el antiguo artículo 607.2 CP, al entender que se castigaba la mera divulgación de un pensamiento, sin exigir la lesión de ningún bien protegido ${ }^{28}$. En este sentido, afirma que "nuestro ordenamiento constitucional no permite la tipificación como delito de la mera transmisión de ideas, ni siquiera en los casos

27 STC 214/1991, de 11 de noviembre (F.J.8).

28 Un comentario sobre la cuestión de inconstitucionalidad que dio lugar a este proceso en, GARCÍA ÁLVAREZ, P.: El Derecho penal y la discriminación, Tirant lo Blanch, Valencia, 2004, pp. 52 y ss. 
en que se trate de ideas execrables por resultar contrarias a la dignidad humana" 29 . Argumenta que el precepto resultaría conforme a la Constitución si se pudiera deducir del mismo que la conducta sancionada implica necesariamente una incitación directa a la violencia contra determinados grupos o un menosprecio hacia las víctimas de los delitos de genocidio $^{30}$.

El Tribunal se plantea si esa acción puede considerarse una manifestación del "discurso del odio" que el TEDH excluye del derecho a la libertad de expresión del artículo 10 $\mathrm{CEDH}^{31}$. Y afirma que "la conclusión ha de ser negativa ya que dicho discurso viene definido - en la ya citada STEDH Ergogdu e Ince c. Turquía, de 8 de julio de 1999- como aquél que, por sus propios términos, supone una incitación directa a la violencia contra los ciudadanos o contra determinadas razas o creencias" 32 .

En cambio, a continuación, analiza la segunda conducta prevista en el mismo apartado, la difusión de ideas o doctrinas que justifiquen los delitos de genocidio, y en este caso mantiene una postura más laxa. Sostiene que, "la especial peligrosidad de delitos tan odiosos y que ponen en riesgo la esencia misma de nuestra sociedad permite excepcionalmente que el legislador penal sin quebranto constitucional castigue la justificación pública de ese delito, siempre que tal justificación opere como incitación indirecta a su comisión".

En este caso, el Tribunal sí fundamenta la sanción de esta expresión por ser una manifestación del "discurso del odio", aunque parece mantener una concepción más amplia de esta figura que en el Fundamento anterior ${ }^{33}$ : "El

\footnotetext{
29 STC 235/2007 (F.J.6).

30 STC 235/2007 (F.J.7).

31 STC 235/2007 (F.J.8).

32 La cursiva que parece en los siguientes apartados del texto en añadida.

33 Ponen de relieve la improcedencia de la expresión "discurso del odio" como fundamento de la sanción penal, REVENGA SÁNCHEZ, M.:
} 
entendimiento de la difusión punible de conductas justificadoras del genocidio como una manifestación del «discurso del odio» está, además, en absoluta consonancia con los textos internacionales más recientes. Así, el artículo 1 de la Propuesta de Decisión Marco relativa a la lucha contra el racismo y la xenofobia..., limita la obligación de los Estados miembros de adoptar medidas para garantizar que se castigue la apología pública, la negación o la trivialización flagrante de los crímenes de genocidio a los casos en los que «la conducta se ejecute de tal manera que pueda implicar una incitación a la violencia o al odio contra el grupo social afectado»".

Resulta llamativo que respecto a la negación del genocidio precise una provocación directa a la violencia, o un menosprecio hacia las víctimas, y en la justificación de ese delito baste la incitación indirecta a cometerlo. Incluso, habla de un modo vago de que esta conducta conlleve el riesgo cierto de generar un clima de violencia y hostilidad, o de provocar de modo mediato al odio, la violencia o la discriminación ${ }^{34}$. En

"Los discursos del odio y la democracia adjetivada: tolerante, intransigente, ¿militante?”, en REVENGA SÁNCHEZ, M. (Dir.): Libertad de expresión y discursos del odio, Universidad de Alcalá, 2015, p. 18; REY MARTÍNEZ, F.: "Discurso del odio y racismo líquido", en REVENGA SÁNCHEZ, M. (Dir.): Libertad de expresión..., cit., p. 52; y, VIVES ANTÓN, T.S.: "Sobre la apología del terrorismo como "discurso" del odio”, en REVENGA SÁNCHEZ, M. (Dir.): Libertad de expresión..., cit., pp. 36 y 37.

34 Puede verse una crítica en, ALASTUEY DOBÓN, C.: "La reforma de los delitos de provocación al odio y justificación del genocidio en el Proyecto de Ley de 2013: consideraciones críticas (1)", en Diario La Ley, ${ }^{\circ}$ 8245, 2014, pp. 9 y 10; LASCURAÍN SÁNCHEZ, J.A.: "La libertad de expresión tenía un precio. (Sobre la STC 235/2007, de inconstitucionalidad del delito de negación del genocidio)", en Revista Aranzadi Doctrinal, n 6, 2010, pp. 69 y ss; MARTÍNEZ SOSPEDRA, M.: "Aplastar a una serpiente en el huevo. Acerca de la cuestión de inconstitucionalidad promovida contra el artículo 607.2 del CP", en Revista General de Derecho, $\mathrm{n}^{\circ}$ 664-665, 2000, pp. 99 y ss; y, RAMOS VÁZQUEZ, J.A.: "La declaración de inconstitucionalidad del delito de «negacionismo» (art. 607.2 del Código penal)", en Revista Penal, $\mathrm{n}^{\circ} 23,2009$, pp. 127 y ss. 
todo caso, estos argumentos vienen precedidos por la exigencia de que la difusión de ideas o doctrinas que justifiquen el genocidio incite indirectamente a realizar el delito, por lo que cabe entender que esos razonamientos siguientes son formas de expresar ese presupuesto previo ${ }^{35}$.

En definitiva, en el marco del artículo 607.2, el "discurso del odio" requería una provocación a la violencia o una ofensa a la dignidad de las víctimas, o una incitación indirecta a cometer el delito de genocidio ${ }^{36}$.

Sin embargo, después de esta sentencia el Tribunal Constitucional manejó una noción más extensa del "discurso del odio", aunque en realidad bajo esta fórmula ambigua quiso dar cobertura a la condena de expresiones que debieron quedar cubiertas por el artículo 20.1 CE. En cambio, en sede de terrorismo ha redefinido ese discurso restringiendo de nuevo su contenido.

35 Entiende que según el Tribunal Constitucional la difusión de ideas que justifiquen el genocidio requiere que tenga capacidad -indirecta, aunque real- incitadora del delito de genocidio. LANDA GOROSTIZA, J.M.: "Incitación al odio: evolución jurisprudencial (1995-2011) del art. 510 CP y propuesta de lege lata", en Revista de Derecho Penal y Criminología, $\mathrm{n}^{\circ}$ 7, 2012, p. 336.

36 Para LAURENZO COPELLO la esencia de la ilicitud de las conductas del artículo 607.2 residiría en el mensaje de hostilidad y desprecio hacia el colectivo afectado por el genocidio, de modo que se atacaba su dignidad. LAURENZO COPELLO, P.: "Marco de protección jurídico penal del derecho a no ser discriminado. Racismo y xenofobia", en MAQUEDA ABREU, M.L. (Dir.): Libertad ideológica y derecho a no ser discriminado, Cuadernos de Derecho Judicial, 1996, p. 241. En cambio, a juicio de Cuerda Arnau se trataba de un delito formal, carente de bien jurídico. CUERDA ARNAU, M.L.: "El denominado delito de apología del genocidio. Consideraciones constitucionales", en Poder Judicial, $n^{\circ} 56,1999$, pp. 81 y 86. También según Vives Antón esas conductas consistían en la mera transmisión de opiniones. VIVES ANTÓN, T. S.: "Sistema democrático y concepciones del bien jurídico: el problema de la apología del terrorismo", en GÓMEZ COLOMER, J. L./GONZÁLEZ CUSSAC, J. L. (Dir.): Terrorismo y proceso penal acusatorio, Tirant lo Blanch, Valencia, 2006, p. 37. 


\section{El «discurso del odio» en la jurisprudencia posterior}

La STC -Pleno- 177/2015, de 22 de julio, amplió significativamente el concepto de "discurso del odio" mantenido en la STC 235/2007. Para ello, parte de la jurisprudencia del TEDH, pero no adopta la noción del caso Ergogdu e Ince c. Turquía, de 8 de julio de 1999, que precisa una inducción directa a la violencia, sino la del caso Féret c. Bélgica, de 16 de julio de 2009, que niega la necesidad de violencia u otros actos delictivos. Además, da un contenido novedoso a ese discurso, con el fin de encajar en él el supuesto particular que se estaba juzgando.

En principio, señala que "la jurisprudencia del TEDH ha afirmado que «la tolerancia y el respeto de la igual dignidad de todos los seres humanos constituyen el fundamento de una sociedad democrática y pluralista. De ello resulta que, en principio, se puede considerar necesario, en las sociedades democráticas, sancionar e incluso prevenir todas las formas de expresión que propaguen, inciten, promuevan o justifiquen el odio basado en la intolerancia» (...caso Féret c. Bélgica, § 64)"37.

Por este cauce, el Tribunal Constitucional trata de fundar la condena impuesta a los recurrentes por un delito de injurias cualificado del artículo $490.3 \mathrm{CP}$, por quemar en público una fotografía de los Reyes, basándose, no en la ofensa al honor como argumentó la Audiencia Nacional, sino en que ese hecho era "discurso del odio" e incitaba a la violencia contra los Monarcas. De este modo, quiso adecuarse a la sentencia del caso STEDH del caso Otegi Mondragón c. España, de 15 de marzo de 2011. En ella la Corte declaró que el artículo 490.3 CP no es conforme al CEDH, porque prevé una penalidad más grave que la establecida para las injurias a otras instituciones. Además, señaló que el criterio decisivo para limitar la libertad de expresión en el debate sobre

37 STC-Pleno-177/2015, de 22 de julio (F.J.2). 
asuntos de interés público es la existencia de manifestaciones que inciten a la violencia o sean "discurso del odio".

Atendiendo a este último elemento, el Tribunal Constitucional incluye la quema del retrato de los Reyes en el "discurso del odio": "Es obvio que las manifestaciones más toscas del denominado "discurso del odio» son las que se proyectan sobre las condiciones étnicas, religiosas, culturales o sexuales de las personas. Pero lo cierto es que el discurso fóbico ofrece también otras vertientes, siendo una de ellas, indudablemente, la que persigue fomentar el rechazo y la exclusión de la vida política, y aun la eliminación física, de quienes no compartan el ideario de los intolerantes" ${ }^{38}$.

Como era de esperar, esta sentencia mereció duras críticas en la citada STEDH del caso Stern Taulats y Roura Capellera c. España, de 13 de marzo de 2018, que comento ampliamente en otro trabajo ${ }^{39}$. Es evidente que esa definición no encaja en el concepto de "discurso del odio" que ha mantenido el TEDH, ni tampoco en el que había manejado antes el propio Tribunal Constitucional. De igual forma, quedó claro que el hecho juzgado no incitó a la violencia contra los Monarcas. De hecho, en el recurso ante la Corte europea el Gobierno alegó los incidentes violentos que tuvieron lugar días más tarde, con motivo de la detención de los inculpados, altercados que obviamente no estuvieron provocados por la quema de la fotografía, y no se dirigieron contra los Reyes, sino que fueron una forma de protesta frente a una decisión judicial. Pero lo fundamental es que en la STC -Pleno- $177 / 2015$, de 22 de julio, se mantuvo la condena en virtud de un precepto, el artículo $490.3 \mathrm{CP}$, que la Corte había declarado contrario al CEDH, por aplicar una pena superior a las injurias a los Reyes que a las dirigidas a otras instituciones. Me parece indudable que lo que debió hacer el Tribunal

38 STC-Pleno-177/2015, de 22 de julio (F.J.4).

39 ROIG TORRES, M.: Delimitación entre libertad de expresión y «discurso del odio»..., cit., pp. 137 y ss. 
Constitucional fue conceder el amparo a los recurrentes y declarar que la destrucción del retrato forma parte del derecho fundamental a la libertad de expresión. A la vista de la STEDH del caso Otegi Mondragón c. España su respuesta resulta totalmente reprochable.

Más tarde, la STC 112/2016, de 20 de junio, aludió a la concepción mantenida en esa resolución. Ahora bien, a continuación, requirió un elemento no recogido en el artículo 578.1 CP para sancionar el enaltecimiento y la justificación públicos del terrorismo, restringiendo el "discurso del odio" punible en este campo.

\section{Aplicación de la STC 235/2007 al enaltecimiento y justificación del terrorismo}

El Tribunal Constitucional ha considerado que el enaltecimiento y la justificación públicos de los delitos de terrorismo, o de quienes hayan participado en su ejecución, que prevé el artículo $578.1 \mathrm{CP}^{40}$, son formas de "discurso

40 Critican esta disposición, entre otros, CANCIO MELIÁ, M., Los delitos de terrorismo: estructura típica e injusto, Reus, Madrid, 2010, pp. 272 y ss; CARBONELL MATEU, J.C.: "Crítica a los sentimientos como bien jurídico-penal", en Liber Amicorum. Estudios Jurídicos en Homenaje al Prof. Dr. Dr. H.c. Juan $M^{a}$ Terradillos Basoco, Tirant lo Blanch, Valencia, 2018, pp. 9 y 10; CUERDA ARNAU, M.L.: "El nuevo delito...", cit., pp. 89 y ss; MIRA BENAVENT, J: "El delito de enaltecimiento del terrorismo, el de humillación a las víctimas del terrorismo y la competencia de la Audiencia Nacional: ni delito, ni terrorismo, ni competencia de la Audiencia Nacional", en ALONSO RIMO, A./CUERDA ARNAU, M.L./FERNÁNDEZ HERNÁNDEZ, A. (Dir.): Terrorismo, sistema penal $y$ derechos fundamentales, Tirant lo Blanch, Valencia, 2018, p. 302; MUÑOZ CONDE, F.: Derecho penal. Parte especial, $20^{\mathrm{a}}$ edición, Tirant lo Blanch, Valencia, 2015, p. 798; SÁEZ VALCÁRCEL, J.R.: "Apología del terrorismo...", cit., pp. 2 y ss; TERUEL LOZANO, G.M.: "Expresiones intolerantes, delitos de odio y libertad de expresión: un difícil equilibrio", en Revista Jurídica de la Universidad Autónoma de Madrid, no 36, 2017-II, pp. 191 y ss; y, VIVES ANTÓN, T.S.: "Sistema democrático y concepciones del bien jurídico: el problema de la apología del terrorismo", en Estudios Penales y Criminológicos, vol. XXV, 2005 , pp. 424 y ss. 
del odio" y les ha aplicado la doctrina sentada en la STC $235 / 2007$, exigiendo para condenar que esas declaraciones conlleven cierto peligro no previsto en ese precepto ${ }^{41}$.

En esta dirección se pronunció por primera vez en el ATC 4/2008, de 9 de enero, donde ya afirmo que, "la condena por el delito de enaltecimiento o justificación de los delitos de terrorismo o de sus autores (art. $578 \mathrm{CP}$ ) supone una vulneración del derecho a la libertad de expresión, pues, como se afirma en la STC 235/2007, en relación con los delitos de genocidio, «la especial peligrosidad de delitos tan odiosos y que ponen en riesgo la esencia misma de nuestra sociedad" - cosa que debe afirmarse ahora también de los delitos de terrorismo - «permite excepcionalmente que el legislador penal sin quebranto constitucional castigue la justificación pública de ese delito, siempre que tal justificación opere como incitación indirecta a su comisión».

El enaltecimiento y la justificación de los delitos de terrorismo o de sus autores solo podrán sancionarse cuando inciten, al menos indirectamente, a realizarlos.

Esta postura se plasmó en la STC 112/2016, de 20 de junio, que aplicaba la tesis de la STC 235/2007 a ese delito, basándose en su "similitud estructural" con la difusión de ideas o doctrinas que nieguen o justifiquen el genocidio, examinada en esta resolución ${ }^{42}$.

41 Entiende que son conductas de opinión que por su contenido o su contexto pueden afectar a bienes jurídicos penalmente protegidos como la seguridad ciudadana o el orden constitucional, BERNAL DEL CASTILLO, J.: "El enaltecimiento del terrorismo...", cit., pp. 19 y ss.

42 "La concreta cuestión de la eventual incidencia que podría tener la sanción de un delito de enaltecimiento del terrorismo en el derecho a la libertad de expresión no ha sido todavía objeto de ningún pronunciamiento de este Tribunal mediante Sentencia. Ahora bien, por la similitud estructural que presentan ambos tipos penales y por su incidencia sobre el derecho fundamental invocado, resulta necesario recordar la doctrina establecida en la STC 235/2007, de 7 de noviembre, en la que se analiza la constitucionalidad de los tipos penales referidos a la negación y difusión de ideas que justifiquen el genocidio" (F.J.3). 
El Tribunal Constitucional recuerda que "en la STC 235/2007, en relación con los delitos de genocidio se afirmaba que «la especial peligrosidad de delitos tan odiosos y que ponen en riesgo la esencia misma de nuestra sociedad permite excepcionalmente que el legislador penal sin quebranto constitucional castigue la justificación pública de ese delito, siempre que tal justificación opere como incitación indirecta a su comisión»...Esa idea de la necesidad de que la justificación opere como una incitación indirecta a la comisión del delito fue la que determinó que la STC 235/2007 declarara la inconstitucionalidad del delito de negación del genocidio, ante la ausencia de ese elemento de incitación en su tipificación... E, igualmente, fue la exigencia interpretativa de que debiera concurrir ese elemento de incitación en el delito de la difusión de ideas que justifiquen el genocidio, lo que permitió mantener su constitucionalidad..., «siempre que tal justificación opere como incitación indirecta a su comisión; esto es incriminándose (y ello es lo que ha de entenderse que realiza el art. 607.2 CP) conductas que aunque sea de forma indirecta supongan una provocación al genocidio. Por ello, el legislador puede, dentro de su libertad de configuración, perseguir tales conductas, incluso haciéndolas merecedoras de reproche penal siempre que no se entienda incluida en ellas la mera adhesión ideológica a posiciones políticas de cualquier tipo, que resultaría plenamente amparada por el artículo $16 \mathrm{CE} \mathrm{y,}$ en conexión, por el artículo $20 \mathrm{CE} » " 43$.

Añade que "esta exigencia de que la sanción penal de las conductas de enaltecimiento o justificación de actos terroristas o de sus autores ${ }^{44}$ requiere, como una manifestación del

43 Destacaba la importancia de evitar el "efecto desaliento" al valorar la proporcionalidad de esta figura, CUERDA ARNAU, M.L.: "Proporcionalidad penal y libertad de expresión: la función dogmática del efecto desaliento", en Revista General de Derecho Penal, no 8, 2007, p. 28; y, CUERDA ARNAU, M.: "Terrorismo y libertades políticas", en Teoría \& Derecho: Revista de Pensamiento Jurídico, n 3, 2008, p. 46.

44 El Tribunal Constitucional habla en el Fundamento 2 de "autores y partícipes" al definir el enaltecimiento. Sin embargo, en la fundamentación sucesiva se refiere solo a los autores. 
discurso del odio ${ }^{45}$, una situación de riesgo para las personas o derechos de terceros o para el propio sistema de libertades como condición para justificar su compatibilidad con el estándar del derecho de la libertad de expresión por ser necesaria esa injerencia en una sociedad democrática también aparece en el contexto internacional y regional europeo" ${ }^{46}$.

En consecuencia, "la sanción penal de las conductas de enaltecimiento del terrorismo sancionadas en el artículo $578 \ldots$, supone una legítima injerencia en el ámbito de la libertad de expresión de sus autores en la medida en que puedan ser consideradas como una manifestación del «discurso del

45 Dice VIVES ANTÓN que con la equívoca expresión "discurso del odio" parece que pretenda cubrirse el déficit de legitimidad del castigo de ciertas expresiones que deberían quedar amparadas por la libertad de expresión. VIVES ANTÓN, T.S.: "Sobre la apología del terrorismo como discurso del odio", en VIVES ANTÓN, T.S.: Pensar la libertad..., cit., p. 513.

46 En concreto, cita el Convenio del Consejo de Europa para la prevención del terrorismo, de 16 de mayo de 2005, que impone a los Estados, entre ellos España, la tipificación como delito de la provocación pública a cometer delitos de terrorismo. Define tal provocación, como la difusión de mensajes con la intención de incitar a cometer delitos terroristas, cuando ese comportamiento ya preconice directamente o no la comisión de delitos terroristas, cree peligro de que se puedan cometer uno o varios delitos. Además, indica que en la Decisión Marco 2008/919/JAI del Consejo, de 28 de noviembre de 2008, se establece que se entenderá por " "provocación a la comisión de un delito de terrorismo» la distribución o difusión pública, por cualquier medio, de mensajes destinados a inducir a la comisión de cualesquiera de los delitos enumerados en el artículo 1, apartado 1, letras a) a h), cuando dicha conducta, independientemente de que promueva o no directamente la comisión de delitos de terrorismo, conlleve el riesgo de comisión de uno o algunos de dichos delitos" (F.J.3). Igualmente, recuerda que según la jurisprudencia del TEDH relativa a la sanción penal de la incitación o apología del terrorismo, podría resultar justificada una limitación de la libertad de expresión cuando pueda inferirse que dichas conductas supongan un riesgo para la seguridad nacional, la integridad territorial o la seguridad pública, la defensa del orden o la prevención del delito. En aplicación de esta doctrina, ha rechazado las demandas cuando las conductas eran manifestación del discurso del odio por justificar el recurso a la violencia para la consecución de objetivos políticos (F.J.4). 
odio» por propiciar o alentar, aunque sea de manera indirecta, una situación de riesgo para las personas o derechos de terceros o para el propio sistema de libertades".

"Por tanto, la labor de control de constitucionalidad que bajo la invocación del derecho a la libertad de expresión [art. 20.1 a) CE] debe desarrollarse en este procedimiento de amparo debe quedar limitada, a verificar si en este caso las resoluciones judiciales impugnadas..., han ponderado esa concreta exigencia, como elemento determinante delimitador de la constitucionalidad, de que la conducta desarrollada por el recurrente pudiera ser considerada una manifestación del "discurso del odio», que incitaba a la violencia" 47 .

En conclusión, deniega el amparo al demandante, toda vez que su conducta, "por ser una manifestación del «discurso del odio", que incitaba a la violencia", a través del enaltecimiento del autor de actividades terroristas, no puede quedar amparada por el derecho a la libertad de expresión (art. 20.1 CE) ${ }^{48}$.

Así pues, afirma que en la STC 235/2007 requirió que la difusión de ideas que justifiquen el genocidio ha de suponer una incitación indirecta a cometer este delito para que su sanción penal sea compatible con el artículo 20.1 CE.

Trasladando este principio al delito de enaltecimiento y justificación públicos del terrorismo o de sus autores del artículo $578.1 \mathrm{CP}$, declara que solo es conforme con aquella norma, cuando esas expresiones creen una situación de riesgo para las personas o derechos de terceros o para el propio sistema de libertades, es decir, cuando entrañen una incitación indirecta a cometer delitos de terrorismo o a emplear la violencia.

Más tarde, la STC 35/2020, de 25 de febrero ${ }^{49}$, transcribió la fundamentación de la STC 112/2016, en cuanto a la

47 STC 112/2016, de 20 de junio (F.J.4).

48 STC 112/2016, de 20 de junio (F.J.6).

49 Sobre esta sentencia, CORRECHER MIRA, J.: “¿Fin de la broma?..”, cit., pp. 8 y ss. 
conexión con la STC 235/2007 y con la normativa internacional y la jurisprudencia del TEDH relativas al enaltecimiento del terrorismo. Igualmente, incluye la necesidad de que, el enaltecimiento o justificación de actos terroristas o de quienes los ejecuten, como una manifestación del discurso del odio, conlleven una situación de riesgo para las personas o derechos de terceros o para el propio sistema de libertades como condición para que su sanción sea conciliable con el artículo 20.1. $\mathrm{CE}^{50}$. No obstante, en esta ocasión estima el recurso de amparo por haberse vulnerado la libertad de expresión del condenado, debido a que la sentencia condenatoria no ponderó debidamente las circunstancias concurrentes antes de aplicar el tipo penal, partiendo del predominio de ese derecho fundamental en nuestro Estado democrático ${ }^{51}$.

En suma, para que el citado delito del artículo 578.1 CP sea conforme a la Norma Fundamental, el Tribunal Constitucional requiere que la expresión concreta cree una situación de riesgo para las personas o derechos de terceros o para el propio sistema de libertades, y esta situación de peligro la interpreta como una provocación indirecta a la comisión de delitos de terrorismo o a la violencia.

Mediante la lectura adoptada en esas sentencias se adecua nuestra legislación a la jurisprudencia del TEDH, pues como se vio la Corte admite la sanción penal de las declaraciones de apoyo al terrorismo, cuando mueven al uso de violencia.

Desde luego, por muy odiosos y peligrosos que sean los delitos de terrorismo, no pueden obviarse varios principios fundamentales de nuestro Estado democrático, a la hora de castigar el enaltecimiento y la justificación de esos actos. Primero, que en la medida en que su punición supone un recorte de la libertad de expresión del artículo 20.1 CE,

50 STC 35/2020, de 25 de febrero (F.J.4).

51 STC 35/2020, de 25 de febrero (F.J.5). 
han de ponderarse los bienes afectados por esas declaraciones partiendo de la preeminencia reconocida a este derecho. Desde esta premisa, es obvio que la reacción penal no puede responder a la indignación social, ni al reproche que merecen los delitos ensalzados, como apuntaba el legislador en la Exposición de Motivos de la LO 7/2000, de 22 de diciembre ${ }^{52}$. $\mathrm{Ni}$ siquiera cabe basarla en la oposición formal a los valores esenciales proclamados en nuestra Constitución, que el autor revela a través del enaltecimiento de crímenes tan repudiables. Según señala el Tribunal Constitucional, en nuestro sistema no tiene cabida un modelo de "democracia militante", donde se imponga, no ya el respeto, sino la adhesión positiva al ordenamiento y, en primer lugar, a la Norma Fundamental. Esta opción tiene repercusiones trascendentes en el orden penal, porque implica admitir que la defensa y la persecución de objetivos contrarios a los principios constitucionales es legítima y forma parte de la libertad de expresión, siempre que no se realicen actos contrarios a la ley y se respeten los procedimientos de reforma constitucional ${ }^{53}$. Por otra parte, no hay que olvidar que, con carácter general el artículo 18 $\mathrm{CP}$ requiere una incitación directa al delito para castigar la apología, lo que en buena lógica debería llevar a contemplar esta exigencia en todos los tipos de enaltecimiento, de forma que solo se restringiera la libertad de expresión cuando las declaraciones fueran claramente peligrosas para la convivencia externa.

52 En ella indica que ese delito tiene como fin "perseguir la exaltación de los métodos terroristas, radicalmente ilegítimos desde cualquier perspectiva constitucional, o de los autores de estos delitos, así como las conductas especialmente perversas de quienes calumnian o humillan a las víctimas al tiempo que incrementan el horror de sus familiares. Actos todos ellos que producen perplejidad e indignación en la sociedad y que merecen un claro reproche penal".

53 SSTC 48/2003, de 12 de marzo (F.J.7), 235/2007, de 7 de noviembre (F.J.4), 12/2008, de 29 de enero (F.J.6), 103/2008, de 11 de septiembre (F.J.8), 126/2009, de 21 de mayo (F.J.9), 42/2014, de 25 de marzo (F.J.4), y, 111/2019, de 2 de octubre (F.J.3). 


\section{EI enaltecimiento y justificación de los delitos previstos en el artículo $510 \mathrm{CP}$}

\section{El enaltecimiento de los delitos de genocidio}

\subsection{Origen $y$ ratio legis}

El artículo 510, apartado 1 c) CP castiga con una pena de prisión de uno a cuatro años y multa de seis a doce meses, a quienes públicamente nieguen, trivialicen gravemente o enaltezcan los delitos de genocidio, de lesa humanidad o contra las personas y bienes protegidos en caso de conflicto armado, o enaltezcan a sus autores, cuando se hubieran cometido contra un grupo o una parte del mismo, o contra una persona determinada por razón de su pertenencia al mismo, por los motivos de intolerancia que se indican ${ }^{54}$, y de este modo se promueva o favorezca un clima de violencia, hostilidad, odio o discriminación contra los mismos.

La Exposición de Motivos de la LO 1/2015 justificaba el contenido de los artículos 510 y 510 bis CP, en la finalidad de adecuar la regulación de estas conductas a la Decisión Marco 2008/913/JAI y en el hecho de que el Tribunal Constitucional haya impuesto que la negación del genocidio solamente puede ser delictiva como forma de incitación al odio o a la hostilidad.

En realidad, la Decisión Marco establecía la obligación de los Estados miembros de castigar la apología pública, la negación o la trivialización flagrante de los crímenes de genocidio, crímenes contra la humanidad y crímenes de guerra, contra un grupo o sus miembros, por motivos racistas o

54 “... por motivos racistas, antisemitas u otros referentes a la ideología, religión o creencias, la situación familiar o la pertenencia de sus miembros a una etnia, raza o nación, su origen nacional, su sexo, orientación o identidad sexual, por razones de género, enfermedad o discapacidad...”. La referencia a las razones de género se añadió durante la tramitación en el Congreso, a propuesta del Grupo Parlamentario Mixto (Enmienda ${ }^{\circ}$ 609). 
xenófobos, cuando las conductas puedan incitar a la violencia o al odio contra los mismos ${ }^{55}$.

Por lo tanto, se hablaba de "apología" y no de enaltecimiento, si bien su previsión junto a la negación y trivialización flagrante era indicativa de que ese término se utilizaba en su sentido genérico de alabanza o ensalzamiento y no, obviamente, con un significado más técnico, como el de nuestro artículo $18 \mathrm{CP}$.

Así lo recogieron los Anteproyectos de reforma del Código penal, que cristalizaron en la LO 1/2015, estableciendo para la apología de los delitos de genocidio de lesa humanidad o contra las personas y bienes protegidos en caso de conflicto armado, una pena de prisión de seis meses a dos años y multa de seis a doce meses, igual a la prevista para el enaltecimiento y justificación de los demás delitos contra los grupos señalados o sus miembros, ahora regulados en el artículo 510, apartado 2 b) $\mathrm{CP}^{56}$.

55 Artículo 1. Delitos de carácter racista y xenófobo: "1. Cada estado miembro adoptará las medidas necesarias para garantizar que se castiguen las siguientes conductas intencionadas:... c) la apología pública, la negación o la trivialización flagrante de los crímenes de genocidio, crímenes contra la humanidad y crímenes de guerra tal como se definen en los artículos 6, 7 y 8 del Estatuto de la Corte Penal Internacional, dirigida contra un grupo de personas o un miembro de tal grupo definido en relación con la raza, el color, la religión, la ascendencia o el origen nacional o étnico cuando las conductas puedan incitar a la violencia o al odio contra tal grupo o un miembro del mismo; d) la apología pública, la negación o la trivialización flagrante de los crímenes definidos en el artículo 6 del Estatuto del Tribunal Militar Internacional adjunto al Acuerdo de Londres, de 8 de agosto de 1945, dirigida contra un grupo de personas o un miembro de tal grupo definido en relación con la raza, el color, la religión, la ascendencia o el origen nacional o étnico cuando las conductas puedan incitar a la violencia o al odio contra tal grupo o un miembro del mismo".

56 Anteproyecto de Ley Orgánica por la que se modifica la Ley Orgánica 10/1995, de 23 de noviembre, del Código Penal, de 16 de julio de 2012, y Anteproyecto de Ley Orgánica por la que se modifica la Ley Orgánica 10/1995, de 23 de noviembre, del Código Penal, de 11 de octubre de 2012. 
Sin embargo, el Consejo General del Poder Judicial en su informe sobre el Anteproyecto, señalaba que de acuerdo con el artículo $18 \mathrm{CP}$ la gravedad de la apología era cualitativamente superior a la negación o trivialización de tales crímenes. Además, argumentaba que por su entidad era comparable a las conductas de quienes fomenten, promuevan o inciten directa o indirectamente al odio, hostilidad, discriminación o violencia contra los grupos y personas protegidos ${ }^{57}$. Por eso, en el Proyecto se sustituyó la expresión "hagan apología" por "enaltezcan" y se incrementó la pena, que pasaba a ser de prisión de uno a cuatro años y multa de seis a doce meses $^{58}$, equiparándola a la de esas otras acciones. De esta forma, no solo se elevó la sanción para el enaltecimiento, sino también para la negación y trivialización grave de los delitos indicados, que se asimilaban también a aquellas actuaciones, manteniéndose esta redacción en la versión definitiva de la ley (art.510.1 a y b CP).

Por lo tanto, ese aumento de la penalidad del enaltecimiento no venía acompañado de la previsión de los elementos propios de la apología, pues no se requería la incitación directa a cometer los delitos de genocidio, de lesa humanidad o contra las personas y bienes protegidos en caso de conflicto armado, sino que bastaba fomentar un clima de violencia, hostilidad, odio o discriminación.

Por otra parte, ni en el Anteproyecto ni en el Proyecto se precisaba que la negación, trivialización grave y el enaltecimiento se hicieran de forma pública. Esta deficiencia fue apuntada tanto por la Fiscalía General del Estado ${ }^{59}$, como

57 Informe del Consejo General del Poder Judicial al Anteproyecto de Ley Orgánica por la que se modifica la Ley Orgánica 10/1995, de 23 de noviembre, del Código Penal, de 16 de enero de 2013, pp. 246 y 247.

58 Proyecto de Ley Orgánica por la que se modifica la Ley Orgánica 10/1995, de 23 de noviembre, del Código Penal, de 20 de septiembre de 2013.

59 Informe del Consejo Fiscal al Anteproyecto de Ley Orgánica por la que se modifica la Ley Orgánica 10/1995, de 23 de noviembre, del Código Penal, de 20 de diciembre de 2012, p. 307. 
por el Consejo de Estado ${ }^{60}$, y se corrigió en el Texto remitido por el Congreso de los Diputados al Senado ${ }^{61}$.

\subsection{La equiparación del enaltecimiento a la negación y} trivialización grave

Junto al enaltecimiento se castiga con la misma pena la negación y la trivialización grave, públicamente, de los delitos de genocidio, de lesa humanidad o contra las personas y bienes protegidos en caso de conflicto armado $^{62}$.

El legislador explica la reforma del artículo $510 \mathrm{CP}$ en su conjunto argumentando que el Tribunal Constitucional ha impuesto que la negación del genocidio solo puede constituir delito si es una forma de incitación al odio o a la hostilidad. Pero como se ha visto no es esto lo que dictaminó en la STC 235/2007, sino que la sanción de esa expresión sería constitucional si implicara una incitación directa a la violencia o un menosprecio hacia las víctimas de los delitos de genocidio.

De hecho, en ese proceso el Ministerio Fiscal alegó que toda negación de un delito de genocidio persigue objetivamente crear un clima social de hostilidad contra aquellas personas que pertenezcan a los grupos que en su día sufrieron ese ilícito. El Tribunal Constitucional respondió que aceptar este argumento supondría sustentar la constitucionalidad de ese ilícito en un elemento no contemplado en el tipo, esto es, que la difusión de opiniones que nieguen el genocidio es

60 Dictamen del Consejo de Estado sobre el Anteproyecto de Ley Orgánica por la que se modifica la Ley Orgánica 10/1995, de 23 de noviembre, del Código Penal, de 27 de junio de 2013 (Consideración vigésimo novena).

61 Texto remitido por el Congreso de los Diputados al Senado, publicado en el Boletín de la Cortes Generales, Senado, X Legislatura, n ${ }^{\circ} 465,29$ de enero de 2015.

62 Puede verse una crítica en, ÁLVAREZ GARCÍA, F.J.: "La nueva reforma penal de 2013", en Eunomía. Revista en Cultura de la Legalidad, ${ }^{\circ} 6$, 2014 , pp. 60 y 61. 
idónea para crear una actitud de hostilidad hacia el colectivo afectado, y dice que no cabe afirmar que toda negación sea per se capaz de conseguirlo. Pero se pronuncia sobre el caso hipotético en que se diera esa idoneidad y señala que entonces el juicio de proporcionalidad determinaría que una finalidad meramente preventiva o de aseguramiento no puede justificar una restricción tan radical de estas libertades.

En definitiva, el Tribunal Constitucional estima que la negación pública del genocidio no es en sí adecuada para crear una actitud de hostilidad hacia ciertos colectivos, y añade que en caso de serlo esta capacidad no sería suficiente para fundar la sanción penal.

Por consiguiente, añadir en el tenor de la ley que para castigar esa negación es necesario que promueva o favorezca un clima de violencia, hostilidad, odio o discriminación, no creo que sirva para legitimar su punición desde el punto de vista del artículo 20.1 CE. Por una parte, porque para el Tribunal Constitucional esa expresión no basta para generar una actitud de hostilidad y señala que, aunque así fuera, su sanción sería desproporcionada, ya que no cabe anticipar hasta tal punto la barrera de protección penal. Y, por otra, porque el tipo requiere un efecto todavía menor a esa actitud de hostilidad, precisando tan solo que se promueva o favorezca un "clima" de hostilidad o simplemente de "odio"63.

63 Se habla de "delitos de clima" porque crean un "clima psíquico" adecuado para que proliferen las conductas a las que se incita. LANDA GOROSTIZA, J.M.: "La llamada «mentira de Auschwitz» (art. 607-2 CP) y el «delito de Provocación» (art. 510 CP) a la luz del «caso Varela»: una oportunidad perdida para la «cuestión de inconstitucionalidad» (Comentario a la Sentencia del Juzgado de lo penal $\mathrm{N}^{\circ} 3$ de Barcelona de 16 de noviembre de 1998)", en Actualidad Penal, 1999, pp. 689 y ss; GÓMEZ MARTÍN, V., en CORCOY BIDASOLO, M./MIR PUIG, S. (Dir.): Comentarios al Código penal, Tirant lo Blanch, Valencia, 2015, p. 1604; y, GÓMEZ MARTÍN, V.: "Discurso del odio y principio del hecho", en MIR PUIG, S./CORCOY BIDASOLO, M. (Dir.): Protección penal de la libertad de expresión e información. Una interpretación constitucional, Tirant lo Blanch, Valencia, 2012, pp. 89 y ss. 
Cabe apuntar que esa falta de proporcionalidad se refería a un precepto que entonces señalaba una pena de uno a dos años de prisión, inferior a la fijada en el actual artículo 510, apartado $1 \mathrm{c}) \mathrm{CP}$.

En la STC 235/2007 el Tribunal diferencia la difusión de ideas que nieguen el genocidio y de las que lo justifiquen, y en este supuesto sí estima suficiente la incitación indirecta a cometer ese delito. Por consiguiente, entiende que la justificación pública del genocidio puede conllevar este efecto, aunque no lo recogía expresamente el tipo, mientras que esta posibilidad no la contempla para la negación, que no considera apta para provocarlo. En definitiva, el Tribunal Constitucional entiende que al justificar esos crímenes se puede inducir a actuar contra las personas pertenecientes a los grupos que sufrieron esas atrocidades, mientras la mera negación de tales ilícitos no mueve a actuar, por lo que supone un ejercicio legítimo de la libertad de expresión.

Por lo tanto, es evidente que para el Tribunal Constitucional no son equiparables la justificación y la negación públicas del genocidio. En cambio, en el artículo 510, apartado $1 \mathrm{c}$ ) CP se castigan ambas conductas con la misma pena.

En suma, entiendo que la tipificación de la negación pública del genocidio, de los delitos de lesa humanidad y contra las personas y los bienes protegidos en caso de conflicto armado del artículo 510, apartado $1 \mathrm{c}$ ) $\mathrm{CP}$, es contraria al canon de constitucionalidad fijado en la STC 235/2007 para penalizar la difusión de ideas que nieguen el genocidio desde la óptica del artículo 20.1 CE.

Con mayor motivo creo que esa conclusión es aplicable a la trivialización grave de dichos delitos, prevista en el propio precepto. La trivialización no llega a ser una negación de los hechos, sino que consiste en quitarles importancia ${ }^{64}$, lo

64 Según el Diccionario de la RAE "trivializar" significa "quitar importancia, o no dársela, a una cosa o a un asunto". 
que a la postre supone reconocerlos, pero con menor entidad de la que tuvieron. Además, esa gravedad me parece difícilmente cuantificable.

Es cierto que la Decisión Marco establecía la obligación de los Estados Miembros de castigar penalmente tanto la negación como la trivialización flagrante de los crímenes de genocidio, crímenes contra la humanidad y crímenes de guerra, pero podrían limitar el delito a los supuestos en que se pusiera en peligro el orden público, y en todo caso esa tipificación se vinculaba a la configuración constitucional de la libertad de expresión en cada ordenamiento ${ }^{65}$.

1.3. La promoción o favorecimiento de un clima de violencia, hostilidad, odio o discriminación

Posiblemente, al incluir este elemento en el artículo 510, apartado $1 \mathrm{c}$ ) CP, el legislador quiso cumplir lo dispuesto en la Decisión Marco, donde se preveía que los Estados Miembros deberían castigar las conductas indicadas con una pena máxima de uno a tres años de prisión como mínimo, cuando puedan incitar a la violencia o el odio contra un grupo o sus miembros ${ }^{66}$. Sin embargo, en ese precepto se sustituye este peligro de incitación por el estadio anterior consistente en promover o favorecer un "clima" de violencia, hostilidad, odio o discriminación ${ }^{67}$. Por otra parte, la propia Decisión

65 Artículo 7.2: "La presente Decisión Marco no podrá tener por efecto el de exigir a los Estados miembros la adopción de medidas que contradigan principios fundamentales relativos a las libertades de asociación y expresión, en particular, las libertades de prensa y de expresión en otros medios de comunicación, ni las normas que regulen los derechos y las responsabilidades de la prensa o de otros medios de información, tal como se derivan de tradiciones constitucionales, así como sus garantías procesales, cuando esas normas se refieren al establecimiento o a la limitación de la responsabilidad".

66 Artículo 3.2.

67 Apunta PORTILlA CONTRERAS que, "es cierto que la DM sanciona alguno de los comportamientos recogidos en este apartado del 510 (negar, trivializar) pero exige obligatoriamente una incitación directa 
Marco advierte que se debe respetar la configuración de la libertad de expresión en cada sistema constitucional.

Pues bien, el favorecimiento de ese clima no es equiparable a la incitación indirecta al delito que requirió la STC 235/2007 para que la punición de la difusión de ideas que justifiquen el genocidio sea conforme al artículo 20.1 CE, ni a la incitación a la violencia que precisó la STC 112/2016, para el enaltecimiento o justificación de los delitos de terrorismo ${ }^{68}$.

Hay que pensar que el artículo 510, apartado 1 c) CP solo precisa que las conductas se realicen "públicamente", adoptando la terminología de la Decisión Marco. Pero el artículo 510, apartado $3 \mathrm{CP}$ agrava la pena cuando el delito se comete a través de un medio de comunicación social ${ }^{69}$. De

(apología pública) o indirecta (negación, enaltecimiento) «cuando las conductas puedan incitar a la violencia o al odio...», mientras que el actual Código Penal no habla de incitación sino de actos previos a la incitación, esto es, comportamientos que promuevan o favorezcan un clima de hostilidad, violencia, etc... El artículo 510.1 c) se distancia tanto de la STC 235/2007 como de la propia DM, al sancionar el ámbito de preparación de esas conductas. Resulta incomprensible cómo mediante la negación, trivialización, aunque sea grave, o el enaltecimiento pueden ponerse en peligro los bienes jurídicos protegidos (igualdad o seguridad de los diversos colectivos discriminados). En realidad, no existe ningún peligro para los valores tutelados y sí un ataque permanente a la libertad de expresión". PORTILLA CONTRERAS, G., en QUINTERO OLIVARES, G.: Comentario a la reforma penal de 2015, cit., e-book.

68 Como indica VIVES ANTÓN, según la STC 235/2007 el Tribunal Constitucional no autoriza el castigo de las conductas de negación o trivialización del genocidio en cualquier caso, sino sólo cuando haya un momento de provocación o incitación. Por ello cabe decir que, en este punto, los preceptos del Código precisan, al menos, de una interpretación conforme a la Constitución cuando sea posible; y, en los demás casos merecen una derogación fulminante. VIVES ANTÓN, T.S., en GONZÁlEZ CUSSAC, J.L: (Coord.): Derecho penal. Parte especial, $6^{\mathrm{a}}$ edición, Tirant lo Blanch, Valencia, 2019, pp. 319 y 320.

69 Artículo 510.3 CP: "Las penas previstas en los apartados anteriores se impondrán en su mitad superior cuando los hechos se hubieran llevado a cabo a través de un medio de comunicación social, por medio de internet o mediante el uso de tecnologías de la información, de modo que, aquel se hiciera accesible a un elevado número de personas". 
manera que esa expresión del tipo básico se ha de entender como exposición ante un conjunto de personas ${ }^{70}$, pero sin utilizar estas vías porque entonces prevalecería el delito cualificado.

Por otra parte, de acuerdo con el artículo 510, apartado 1 c) CP basta favorecer o promover un "clima de odio". $\mathrm{Y}$, desde luego, fomentar un ambiente de simple antipatía o aversión ${ }^{71}$, no supone incitar, ni siquiera de manera indirecta, a cometer un delito o a emplear violencia.

La STC 235/2007 partió de la Recomendación No R (97) 20 del Comité de Ministros del Consejo de Europa, que instaba a los Estados miembros a actuar frente al "discurso del odio", incluyendo en él la promoción del odio. Ahora bien, establece que las leyes nacionales deben permitir a los tribunales "que determinadas formas de discurso hostil puedan resultar tan insultantes hacia individuos o grupos como para no disfrutar del nivel de protección que el artículo 10 CEDH garantiza a otras formas de expresión. Así ocurrirá cuando el «discurso del odio» esté dirigido a la destrucción de los derechos y libertades plasmados en el Convenio o a su limitación". El derecho a la libertad de expresión garantizado en este precepto se podrá limitar, pues, cuando las declaraciones sean marcadamente "insultantes" o graves ${ }^{72}$.

70 En el artículo $18.1 \mathrm{CP}$ se admite la provocación por medios de publicidad o ante una "concurrencia de personas", y de acuerdo con el Diccionario de la RAE esta expresión significa "conjunto de personas que asisten a un acto o reunión".

71 Según el Diccionario de la RAE “odiar” significa "antipatía o aversión hacia algo o hacia alguien cuyo mal se desea".

72 Previamente, el artículo 3.3 del Convenio para la prevención y sanción del delito de genocidio de 9 diciembre 1948 estableció que deberá ser castigada "la instigación directa y pública a cometer genocidio". TAMARIT SUMALLA, J.M., en QUINTERO OLIVARES, G. (Dir.)/ MORALES PRATS, F. (Coord.): Comentarios a la Parte especial del Derecho penal, $10^{\text {a }}$ edición, Aranzadi, 2016, e-book. 
Más recientemente, la Recomendación General $\mathrm{N}^{\circ} 15$ relativa a la lucha contra el "discurso del odio", de la Comisión Europea contra el Racismo y la Intolerancia (ECRI) del Consejo de Europa, de 8 de diciembre de $2015^{73}$, incluía también la incitación al odio en el "discurso del odio"74. Sin embargo, señala que la imposición de las sanciones penales "se deja para casos limitados por el riesgo potencial que plantea de vulnerar la libertad de expresión". En concreto, se reserva para los supuestos de incitación a la comisión de actos de violencia, intimidación, hostilidad o discriminación, cuando las expresiones se utilicen en público ${ }^{75}$. Como se ve, ni siquiera se menciona la incitación al odio como fundamento para imponer una pena. Con mayor motivo hay que decir que la creación de un "clima de odio" no es uno de los casos excepcionales en los que el Consejo de Europa estima legítima la imposición de una pena ${ }^{76}$. Además, se habla de incitar a "actos", lo que implica que el "discurso del odio" ha de mover a actuar.

73 (Disponible en: https://rm.coe.int/ecri-general-policy-recommendationn-15-on-combating-hate-speech-adopt/16808b7904).

74 Sobre el concepto de "discurso del odio" en esta disposición, COMAS DE ARGEMIR CENDRA, M.: "Evolución jurisprudencial en los delitos relacionados con el discurso del odio punible: los límites de la libertad de expresión", en Cuadernos Digitales de Formación, Consejo General del Poder Judicial, nº 9, 2017, p. 4; y, ELÓSEGUI ITXASO, M.: "La negación o justificación del genocidio como delito en el derecho europeo. Una propuesta a la luz de la Recomendación $\mathrm{n}^{\circ} 15$ de la ECRI", en Revista de Derecho Político, nº 8, 2017, pp. 252 y ss.

75 Memorandum Explicativo. Responsabilidad penal y sanciones. Recomendación 10 , pp. 60 y 61.

76 Respecto al contexto que propició esas normas para combatir el racismo y la xenofobia, BORJA JIMÉNEZ, E.: "Presupuestos políticocriminales del nacimiento de la legislación penal contra el racismo y la xenofobia en Europa", en GARCÍA AÑÓN, J./RUIZ SANZ, M.: Discriminación racial y étnica, Publicaciones de la Universitat de València, 2013, p. 198; GÓMEZ MARTÍN, V.: "Fighting words, Auschwitzlüge y libertad de expresión", en InterseXiones 4, 2013, pp. 81 y ss; LANDA GOROSTIZA, J.M.: La politica criminal contra la xenofobia y las tendencias expansionistas del Derecho penal, Comares, Granada, 2001, pp. 71 y ss; y, LAURENZO COPELLO, P.: "Marco de protección jurídico penal...", cit., p. 241. 
Es cierto que el TEDH a partir de la primera Recomendación incluyó en el "discurso del odio" la incitación al odio. Pese a ello, solo respalda la condena penal de conductas más graves que, además, fomentan la violencia o la comisión de delitos, o lesionan el honor. A diferencia del Tribunal Constitucional español, la Corte europea no habla de favorecimiento de un "clima" de odio, ni siquiera para legitimar la adopción de formalidades, condiciones, restricciones o sanciones (art. 10.2 CEDH), de naturaleza no penal.

En mi opinión, la criminalización de cualquier conducta que consista en favorecer el odio, o sea, en promover un sentimiento, es totalmente contraria al principio de intervención mínima ${ }^{77}$, por la elemental razón de que el Derecho

77 Critican esta previsión, ALASTUEY DOBÓN, C.: "Discurso del odio y negacionismo en la reforma del Código penal de 2015", en Revista Electrónica de Ciencia Penal y Criminología, 18-14, 2016, p. 10; ALCÁCER GUIRAO, R.: "Discurso del odio y discurso político. En defensa de las libertades de los intolerantes", en Revista Electrónica de Ciencia Penal y Criminología, 14-02, 2012, p. 17. (Disponible en: http://criminet. ugr.es/recpc); CUERDA ARNAU, M., en GONZÁLEZ CUSSAC, J.L. (Coord.): Derecho penal. Parte especial, cit., 2019, p. 754; DEL ROSAL BLASCO, B., en MORILLAS CUEVA, L. (Dir.): Sistema de Derecho penal. Parte especial, 2 ${ }^{\mathrm{a}}$ edición, Dykinson, Madrid, 2016, p. 1288; DÍAZ Y GARCÍA CONLLEDO, M.: "El discurso de odio y el delito de odio de los arts. 510 y 510 bis del Código Penal: Necesidad de limitar", Límites a la libertad de expresión, en Boletín Juezas y Jueces para la Democracia, cit., pp. 18 y ss; GARCÍA ARÁN, M.: "De las reformas bienintencionadas con resultados represivos: el delito de promoción del odio", en MORALES PRATS, F./TAMARIT SUMALLA, J.M./ GARCÍA ALBERO, R. (Coord.): Represión penal y Estado de Derecho. Homenaje al Profesor Gonzalo Quintero Olivares, Aranzadi, Pamplona, 2018, pp. 867 y ss; GARROCHO SALCEDO, A./PORTILLA CONTRERAS, G.: "Delitos de incitación al odio, la hostilidad, la discriminación o la violencia”, en ÁLVAREZ GARCÍA, F.J. (Dir.)/DOPICO GÓMEZ-ALLER, J. (Coord.): Estudio critico sobre el Anteproyecto de reforma penal de 2012, Tirant lo Blanch, Valencia, 2013, p. 933; LAMARCA PÉREZ, C., en LAMARCA PÉREZ, C. (Coord.): Delitos. La parte especial del Derecho penal, $2^{\mathrm{a}}$ edición, Dykinson, Madrid, 2017, p. 955; LANDA GOROSTIZA, J.M.: Los delitos de odio, Tirant lo Blanch, Valencia, 2018, p. 24; LAURENZO COPELLO, P.: "La protec- 
penal solo debe ocuparse de los hechos externos que afecten gravemente a la convivencia.

Asimismo, el favorecimiento de un "clima de hostilidad" es un elemento confuso, que tampoco alcanza el nivel mínimo fijado por el Tribunal Constitucional para limitar la libertad de expresión, consistente en incitar indirectamente al delito o a la violencia. Según el Diccionario de la RAE "hostilidad" significa "cualidad de hostil", "acción hostil" y "agresión armada de un pueblo, ejército o grupo". Y la palabra "hostil" equivale a "contrario o enemigo". Por su parte, la Recomendación de la ECRI de 2015 define "hostilidad" como "una manifestación del odio más allá del estado de ánimo". Pero esta manifestación podría consistir, por ejemplo, en una declaración verbal de antipatía respecto al co-

ción penal frente a las conductas racistas y xenófobas”, en SOROETA LICERAS, J. (Ed.): Cursos de Derechos Humanos de Donostia-San Sebastián, vol. II, Universidad del País Vasco, 1999-2000, pp. 191 y 200; LAURENZO COPELLO, P. "Sentimientos religiosos y delitos de odio: un nuevo escenario para unos delitos olvidados", en Liber Amicorum. Estudios Jurídicos en Homenaje al Prof. Dr. Dr. H.c. Juan $M^{a}$ Terradillos Basoco, Tirant lo Blanch, Valencia, 2018, p. 1295; PORTILLA CONTRERAS, G.: "La represión penal del «Discurso del odio»", en QUINTERO OLIVARES, G. (Dir.): Comentarios a la reforma penal de 2015, cit., e-book; ROIG TORRES, M.: "Los delitos de racismo y discriminación (arts. 510, 510 bis, 511 y 512), en GONZÁLEZ CUSSAC, J.L. (Dir.)/GÓRRIZ ROYO, E./MATALLÍN EVANGELIO, Á. (Coord.): Comentarios a la reforma del código penal de 2015, $2^{\text {a }}$ edición, Tirant lo Blanch, Valencia, 2015, p. 1262; SÁEZ VALCÁRCEL, R.: "La libertad de expresión", Límites a la libertad de expresión, en Boletín Juezas y Jueces para la Democracia, cit., pp. 3 y ss; SAINZ-DÍEZ DE ULZURRUN LLUCH, M.: "El peligro de las palabras. A propósito del delito de apología del genocidio", en CUERDA RIEZU, A./JIMÉNEZ GARCÍA, F. (Dir.): Nuevos desafíos del Derecho penal internacional, Tecnos, Madrid, 2009, p. 324; TAMARIT SUMALLA, J.M.: "Los delitos de odio en las redes sociales", en Revista de Internet, Derecho y Política, $\mathrm{n}^{\circ}$ 27, 2018, p. 2. (Disponible en: https://idp.uoc.edu/articles/10.7238/ idp.v0i27.3151/galley/3491/download/); y, TAPIA BALLESTEROS, P., en GÓMEZ TOMILLO, M./JAVATO MARTÍN, A.M. (Dir.): Comentarios prácticos al Código penal, Tomo VI, Aranzadi, Pamplona, 2015, p 187. 
lectivo o sus miembros. Pensemos que desafortunadamente hay personas con ideas xenófobas y que no por ello actúan contra los inmigrantes. Por consiguiente, crear esa atmósfera de enemistad no comporta aquellas consecuencias.

Lo mismo cabe decir del favorecimiento de un clima de discriminación, puesto que no conlleva tampoco esa provocación.

Por lo demás, la referencia al "clima" y a la "hostilidad" es contraria a la seguridad jurídica que reclama el principio de legalidad ${ }^{78}$. De hecho, tanto el Consejo General del Poder Judicial ${ }^{79}$, como el Consejo Fiscal ${ }^{80}$ y el Consejo de Estado $^{81}$, recomendaron suprimir la mención al clima y hablar en su lugar de incitación directa o indirecta, según figura en la Decisión Marco. En cambio, fue la Fiscalía General del Estado la que en su Memoria previa al Anteproyecto propuso que se incluyera el término "hostilidad"82, por estar previsto en el artículo 20 del Pacto Internacional de Derechos

78 TAMARIT SUMALLA cuestiona la constitucionalidad del artículo 510.1 c) $\mathrm{CP}$ atendiendo al principio de legalidad. TAMARIT SUMALLA, J.M., en QUINTERO OLIVARES, G. (Dir.)/MORALES PRATS, F. (Coord.): Comentarios a la Parte especial del Derecho penal, cit., e-book. Con carácter crítico también, BERNAL DEL CASTILLO, J.: "La justificación y enaltecimiento del genocidio en la Reforma del Código Penal de 2015", en InDret, 2/2016, p. 14; y, DÍAZ Y GARCÍA CONLLEDO, M.: "El discurso de odio...", cit., pp. 18 y ss.

79 Informe del Consejo General del Poder Judicial al Anteproyecto de Ley Orgánica por la que se modifica la Ley Orgánica 10/1995, de 23 de noviembre, del Código Penal, de 16 de enero de 2013, p. 247.

80 Informe del Consejo Fiscal al Anteproyecto de Ley Orgánica por la que se modifica la Ley Orgánica 10/1995, de 23 de noviembre, del Código Penal, de 20 de diciembre de 2012, p. 312.

81 Dictamen del Consejo de Estado sobre el Anteproyecto de ley orgánica por la que se modifica la Ley Orgánica 10/1995, de 23 de noviembre, del Código Penal, de 27 de junio de 2013 (Consideración séptima).

82 Véase, el Informe del Consejo Fiscal al Anteproyecto de Ley Orgánica por la que se modifica la Ley Orgánica 10/1995, de 23 de noviembre, del Código Penal, de 20 de diciembre de 2012, p. 304. 
Civiles y Políticos de $1966^{83}$, pese a que este texto no determinaba la aplicación de una respuesta punitiva.

Por consiguiente, de acuerdo con el principio de taxatividad, entiendo que debería sustituirse el término "clima" por el de "incitación", indirecta según el Tribunal Constitucional, al delito o a la violencia.

1.4. El peligro para la paz pública o la seguridad de las víctimas

El artículo 510, apartado $4 \mathrm{CP}$ dispone que cuando los hechos, a la vista de sus circunstancias, resulten idóneos para alterar la paz pública ${ }^{84} \mathrm{o}$ crear un grave sentimiento de inseguridad o temor entre los integrantes del grupo, se impondrá la pena en su mitad superior, que podrá elevarse hasta la superior en grado.

De esta forma, se confirma que el presupuesto previsto en el artículo 510, apartado $1 \mathrm{c}$ ) $\mathrm{CP}$ consistente en promover o favorecer un clima de violencia, hostilidad, odio o discriminación, se colma al fomentar esta atmósfera.

A mi juicio, dicha regulación no cumple los requisitos señalados en la STC 235/2007. A diferencia del antiguo artículo 607.2, en el artículo 510, apartado 1 c) CP no se castiga la difusión de ideas, sino la expresión pública, que no requiere esa divulgación. Además, se exige tan solo alimentar ese clima, que puede ser odio, y que no conlleva un peligro para la paz pública, ni reviste la entidad suficiente para generar un grave sentimiento de inseguridad o temor entre los integrantes del grupo afectado. Por lo tanto, no induce indirectamente a cometer un delito ni a utilizar violencia.

83 Artículo 20:" ...2. Toda apología del odio nacional, racial, o religioso estará prohibida por la ley".

84 Sobre la diferencia entre la paz pública y el orden público, CUERDA ARNAU, M.L., en GONZÁLEZ CUSSAC, J.L. (Coord.): Derecho penal. Parte especial, cit., p. 788. 
Me parece que estamos ante la exposición de opiniones repudiables, sin lugar a dudas, pero que deben quedar abarcadas por el artículo $20.1 \mathrm{CP}^{85}$. Como declaró entonces el Tribunal Constitucional, "nuestro ordenamiento constitucional no permite la tipificación como delito de la mera transmisión de ideas, ni siquiera en los casos en que se trate de ideas execrables por resultar contrarias a la dignidad humana".

Por otra parte, en este tipo agravado, a diferencia de la Decisión Marco, no se usa el concepto "orden público", sino el de "paz pública". Se sigue, así, la normativa alemana en la que la paz pública constituye, incluso, el bien jurídico protegido en estas conductas.

En concreto, el § $130 \mathrm{StGB}$, en el apartado 3, sanciona con una pena de prisión de hasta cinco años o con multa a quien, públicamente o en una reunión, apruebe, niegue o minimice una acción genocida cometida bajo el régimen del nacionalsocialismo, de una manera que pueda perturbar la paz pública.

El apartado 4 dispone que será castigado con pena de prisión de hasta tres años o con multa, quien públicamente o en una reunión lesione la paz pública de una forma que afecte a la dignidad de las víctimas, al aprobar, glorificar o justificar el régimen de violencia y arbitrariedad nacionalsocialista.

85 Así pues, dice PORTILLA CONTRERAS refiriéndose a los delitos regulados en el artículo $510 \mathrm{CP}$ que "los delitos de «odio» simbolizan el desprecio por la libertad de expresión, creencia e ideología, que hubiera llevado a la hoguera la «Incitación al Nixonicidio y alabanza a la Revolución Chilena» y a Pablo Neruda a la cárcel. Sorprende que aquellos que se indignan ante el asesinato de los redactores de la revista Charlie Hebdo, llegando a identificarse con las caricaturas realizadas en nombre de la libertad de expresión, sean los mismos que tipifican una incitación al odio que privaría de libertad a los autores de tales viñetas". PORTILLA CONTRERAS, G., en QUINTERO OLIVARES, G.: Comentario a la reforma penal de 2015, Aranzadi, Pamplona, 2015, e-book. 
Así pues, en el primer caso es necesario que la conducta ponga en concreto peligro la paz pública y en el segundo que la lesione, además de ofender la dignidad de las vícti$\operatorname{mas}^{86}$.

El Tribunal Constitucional alemán ha interpretado que el peligro o la perturbación de la paz pública se refiere a la convivencia externa, sin que basten los efectos emocionales que la declaración puede provocar. Además, ha entendido que la ofensa de la dignidad de las víctimas está implícita en esas expresiones, dada la gravedad de las atrocidades a las que se refieren ${ }^{87}$. De manera que lo que justifica la proporcionalidad de esas penas es la protección de la paz pública ${ }^{88}$.

En resumen, en el Derecho alemán se entiende que para que resulte proporcionada la pena de esos ilícitos, que puede ser de multa, es necesario que el autor ponga en peligro o altere la convivencia externa. De lo contrario, esas manifestaciones están amparadas por el derecho a la libertad

86 Estas normas han recibido críticas en la doctrina, por entender que no contienen un bien jurídico merecedor de tutela. Para ROXÍN el auténtico sentido es mostrar que hoy en día Alemania es un Estado purificado que no silencia u oculta los delitos de la época de Hitler. ROXÍN, C.: "¿Es la protección de bienes jurídicos una finalidad del Derecho penal?", en HEFENDEHL, R. (Ed.): La teoría del bien jurídico. ¿Fundamento de legitimación del Derecho penal o juego de abalorios dogmáticos?, Marcial Pons, Madrid, 2007, p. 451; y, ROXÍN, C.: "El concepto de bien jurídico como instrumento de crítica legislativa sometido a examen", en Revista Electrónica de Ciencia Penal y Criminología, 15-01, 2013, pp. 9 y 10. Igualmente, Hörnle entiende que la verdadera ratio legis del $\$ 130.3$ StGB se encuentra en el enfado y la intranquilidad de la población. HÖRNLE, T.: "La protección de sentimientos en el StGB", en HEFENDEHL, R. (Ed.): La teoría del bien jurídico..., cit., pp. 391 y 392.

87 Sentencias del Tribunal Constitucional alemán de 4 de noviembre de 2009 (BVerfG 1 BvR 2150/08). (Disponible en: https://www.hrr-strafrecht. de/hrr/bverfg/08/1-bvr-2150-08.php); y, de 22 de junio de 2018 (1 BvR 673/18). (Disponible en: https://www.bundesverfassungsgericht.de/SharedDocs/Entscheidungen/DE/2018/06/rk20180622_1bvr067318.html).

88 STERNBERG-LIEBEN/SCHITTENHELM, en SCHÖNKE, A./ SCHRÖDER, H.: Strafgesetzbuch Kommentar, 30 Auflage, Verlag. C.H. Beck München, 2019, p. 1551. 
de expresión reconocido en el artículo 5.1 de la Ley Fundamental. En cambio, en nuestro ordenamiento el artículo 510, apartado $1 \mathrm{c}$ ) CP no precisa ni siquiera la idoneidad de la conducta para alterar la paz pública, de modo que el delito se agota con el favorecimiento del clima indicado.

Esta discrepancia resulta llamativa, habida cuenta que en Alemania rige un modelo de "democracia militante", en el que se imponen los valores esenciales de la Ley Fundamental, de modo que se prohíben los partidos y asociaciones que defienden otros diferentes ${ }^{89}$.

A mi modo de ver, en nuestro Derecho, donde la libertad de expresión ocupa una posición preeminente, solo deberían penalizarse aquellas expresiones de enaltecimiento o apoyo de un delito que supongan un peligro para la paz pública. En el marco del artículo $510 \mathrm{CP}$, esta regulación sería acorde con la Decisión Marco, puesto que permite penalizar la negación, trivialización y enaltecimiento de los crímenes señalados únicamente cuando se altere el orden público.

En todo caso, la última jurisprudencia constitucional en torno al enaltecimiento y justificación del terrorismo ha requerido algo más que estas declaraciones y entiendo que esa lectura ha de tenerse presente al aplicar aquel precepto.

1.5. El enaltecimiento del genocidio tras la jurisprudencia constitucional relativa al enaltecimiento del terrorismo

En mi opinión, la interpretación del artículo 510, apartado $1 \mathrm{c}) \mathrm{CP}$ se ha visto afectada por la última jurispru-

89 BILBAO UBILLOS, J.M.: "La negación del Holocausto en la jurisprudencia del Tribunal Europeo de Derechos Humanos: la endeble justificación de tipos penales contrarios a la libertad de expresión”, en Revista de Derecho Politico, $\mathrm{n}^{\circ}$ 71-72, 2008, pp. 19 y ss; CAMARERO GONZÁLEZ, G. en GARCÍA, A. (Dir.)/ESCOBAR JIMÉNEZ, R. (Coord.): Código penal. Comentario y jurisprudencia, Comares, Granada, 2018, p. 2794; y, ROSENFELD, M.: "Hate speech in constitutional jurisprudence: a comparative analysis", en Cardozo Law School, n 41, 2001, p. 40. 
dencia constitucional en torno al enaltecimiento del terrorismo. Estas sentencias confirman que no basta la mera promoción del clima que se prevé en esa norma para sancionar el enaltecimiento, negación y trivialización grave del genocidio y de los demás delitos. A la vez, dichas resoluciones generan un problema de deslinde entre ese tipo básico y el cualificado de apartado 4.

En efecto, el artículo 578.1 CP sanciona con una pena de prisión de uno a tres años y multa de doce a dieciocho meses, el enaltecimiento o la justificación públicos de los delitos de terrorismo o de quienes hayan participado en su ejecución. Igualmente, en el apartado 2, se eleva la pena cuando los hechos se hubieran llevado a cabo por un medio de comunicación. Y en el apartado 3 se recoge una figura agravada para los supuestos en que los hechos, a la vista de sus circunstancias, resulten idóneos para alterar gravemente la paz pública o crear un grave sentimiento de inseguridad o temor a la sociedad o parte de ella.

Sin embargo, aun cuando para realizar el tipo básico solo se precisa que el enaltecimiento o la justificación del terrorismo se hagan en público, el Tribunal Constitucional ha declarado que no bastan esas expresiones.

Como se ha visto, el ATC 4/2008 apuntó que esas conductas han de conllevar una provocación indirecta a cometer el delito. Más tarde, las SSTC 112/2016 y 35/2020 requirieron que dichas expresiones puedan considerarse una manifestación del "discurso del odio" por propiciar o alentar, aunque sea de forma indirecta, una situación de riesgo para las personas o derechos de terceros o para el propio sistema de libertades. Por tanto, la primera declara que la labor de control de constitucionalidad, bajo el artículo 20.1 CE, debe limitarse a comprobar si la expresión era discurso del odio, que incitaba a la violencia.

Pues bien, si como afirma el Tribunal Constitucional, los delitos de genocidio y de terrorismo son igualmente 
odiosos y peligrosos para la esencia de nuestra sociedad y su justificación y enaltecimiento merecen el mismo trato por su "similitud estructural", la doctrina que estableció la STC 235/2007 y que ahora se aplica al artículo 578.1 CP, debe regir también para el artículo 510, apartado 1 c) CP. De manera que, de acuerdo con la lectura que el ATC 4/2008 y las SSTC 112/2016 y 35/2020 efectuaron de aquella resolución, el enaltecimiento del genocidio y de los demás delitos o de sus autores, ha de conllevar una incitación indirecta al delito o a realizar actos violentos contra las personas pertenecientes a los colectivos discriminados.

Sin embargo, como expuse, la negación pública del genocidio, e incluso su trivialización, no revisten esa capacidad incitadora, por lo que la punición se debe limitar al enaltecimiento.

Por otra parte, expliqué también que, en mi opinión, no basta la creación del clima que prevé el tipo para provocar esos efectos.

No obstante, a mi juicio la lectura que realiza el Tribunal Constitucional dificulta una interpretación sistemática acorde con el principio de vigencia. Por una parte, esa capacidad incitadora normalmente se dará cuando el enaltecimiento del genocidio, o de los otros delitos, se realice a través de las redes sociales, en cuyo caso regirá el apartado 3 . De todos modos, no hay que descartar que las frases se pronuncien ante una concurrencia de personas, encuadrándose entonces en el artículo 510, apartado 1 c) CP.

Pero, sobre todo, ese entendimiento que requiere una provocación indirecta al delito o a la violencia, hace difícil la distinción respecto al tipo cualificado del apartado 4, donde se incrementa la pena cuando los hechos, a la vista de sus circunstancias, resulten idóneos para alterar la paz pública o crear un grave sentimiento de inseguridad o temor entre los integrantes del grupo. Si el enaltecimiento del genocidio es de tanta entidad como para mover a realizar acciones 
delictivas, a su vez, será idóneo para producir aquellos efectos. De ser así, habrá que aplicar este delito agravado de acuerdo con el principio de alternatividad, dejando sin vigencia real el artículo 510, apartado 1 c) CP. Ciertamente, según la jurisprudencia constitucional esta parece que ha de ser la respuesta, teniendo en cuenta que el tipo básico de enaltecimiento y justificación del terrorismo del artículo 578.1 $\mathrm{CP}$, también va seguido, en el apartado 3 , de una figura agravada para los supuestos de idoneidad para alterar gravemente la paz pública o crear un grave sentimiento de inseguridad o temor. Es más, aquí se requiere esa capacidad para alterar "gravemente" la paz pública, mientras que este adjetivo no se utiliza en el artículo 510, apartado $4 \mathrm{CP}$, de manera que las dificultades de deslinde con el apartado 1 c) son si cabe mayores.

En definitiva, entiendo que de acuerdo con la lectura de la STC 235/2007 efectuada en las SSTC 112/2015 y $35 / 2020$, el enaltecimiento de los delitos de genocidio, de lesa humanidad o contra las personas y los bienes protegidos en caso de conflicto armado, no debe ser punible cuando solo favorezca un clima de violencia, hostilidad, odio o discriminación, sino que además ha de requerirse que inste indirectamente a realizar actos delictivos o a la violencia.

En este punto, también haría falta una mayor concreción por parte del Tribunal Constitucional sobre si se precisa una incitación indirecta a efectuar esos delitos específicos, como afirmó en la STC 235/2007, o si basta alentar a la violencia, según han señalado las SSTC 112/2016 y 35/2020 para el enaltecimiento y justificación del terrorismo. Incluso, atendiendo a la redacción del artículo 510, apartado 1 c) $\mathrm{CP}$ cabe plantearse si es suficiente que el enaltecimiento incite indirectamente a la comisión de otros ilícitos, distintos a los enumerados en este precepto, puesto que únicamente se precisa la promoción de aquel clima y el tipo se dirige a evitar la discriminación y, en definitiva, a tutelar la dignidad de las víctimas. Es decir, la duda reside en si basta incitar 
indirectamente a realizar hechos delictivos contra los miembros de los grupos discriminados. A mi modo de ver, como expondré, esta lectura es la que más se adecua al tenor de la ley y al objeto de tutela.

Esa exégesis, que requiere que el enaltecimiento del artículo 510, apartado 1 c) CP conlleve una provocación indirecta, al delito o a la violencia, está en consonancia con la Recomendación de la ECRI de 2015. En ella, se propone a los Estados Miembros el recurso a la pena frente al "discurso del odio" cuando las declaraciones inciten a realizar actos delictivos $^{90}$.

En cambio, la Fiscalía General del Estado no adoptó este criterio, en la Circular 7/2019, sobre pautas para interpretar los delitos de odio tipificados en el artículo $510 \mathrm{CP}^{91}$. Considera que se trata de delitos de peligro abstracto (a excepción del previsto en el apartado 2 c) que se consuman con la mera emisión del mensaje, que lleva implícito el riesgo re-

90 En la Recomendación 10 se expone que "los factores importantes para que el uso de discurso de odio alcance el límite de responsabilidad penal son los que tienen un carácter más grave, es decir, cuando tienen la finalidad, o quepa suponer razonablemente que van a tener dicho efecto, de incitar a la comisión de actos de violencia, intimidación, hostilidad o discriminación y cuando el uso de expresiones de este tipo tiene lugar en público". Pero en la definición del "discurso del odio" se indica que la Recomendación va más allá del texto del Plan de Acción de Rabat al reconocer que "la intención de incitar a la comisión de actos de violencia, intimidación, hostilidad o discriminación no es imprescindible para esta forma grave de «discurso de odio». Es más, se considera que existe uso de «discurso de odio» también cuando cabe esperar, razonablemente, que como efecto del uso de ese discurso en particular se cometan esos actos delictivos". Añade que "este enfoque es coherente con sentencias del TEDH en las que se reconoce la compatibilidad con el artículo 10 $\mathrm{CEDH}$ sobre la imposición de sanciones penales para las expresiones utilizadas cuando se sabía que podían exacerbar una situación ya explosiva".

91 Circular 7/2019 de la FGE, sobre pautas para interpretar los delitos de odio, pp. 20 y ss. (Disponible en: https://www.boe.es/diario_boe/txt. php?id=BOE-A-2019-7771). 
querido para bienes jurídicos relevantes en el sistema democrático ${ }^{92}$. En este sentido, cita la STS 72/2018, de 9 de febrero, que confirmó la condena del acusado por un delito de incitación al odio del artículo 510, apartados 1 a) y 3 CP. En esta resolución se reconoce que estos ilícitos presentan una "estructura similar" a la del enaltecimiento del terrorismo y se menciona la STC 112/2016, señalando que en ella se declaró "el carácter limitable del derecho a la libertad de expresión, singularmente por las manifestaciones que alienten la violencia”. Pero no dice que el Tribunal Constitucional estableció este presupuesto como ineludible ${ }^{93}$.

En concreto, respecto al artículo 510, apartado 1 c) $\mathrm{CP}$, concluye que, "pese a la utilización de la expresión «clima», que adolece de una cierta indeterminación, los/las

92 Ampliamente, sobre esta Circular, MOLINA BLÁZQUEZ, M.C.: "Valoración crítica de la Circular 7/2019 de la Fiscalía General del Estado...", cit., pp. 1 y ss.

93 La STS 72/2018, de 9 de febrero, se aparta, además, de la postura mantenida por el Tribunal Supremo en sus últimas sentencias sobre el enaltecimiento del terrorismo. En efecto, la STS 354/2017, de 17 de mayo, declaró que según estableció la STC 112/2016, de 20 de junio, el artículo $578 \mathrm{CP}$ solo "supone una legítima injerencia en el ámbito de la libertad de expresión de sus autores en la medida en que puedan ser consideradas como una manifestación del discurso del odio por propiciar o alentar, aunque sea de manera indirecta, una situación de riesgo para las personas o derechos de terceros o para el propio sistema de libertades". Se refiere a la Directiva (UE) 2017/541, que tipifica la provocación pública a la comisión de delitos de terrorismo, incluyendo la apología y la justificación del terrorismo y concluye que esta norma también exige que esas conductas "conlleven el riesgo (no concreto sino de aptitud) de que puedan cometerse actos terroristas" (F.J.4). Igualmente, según la STS $52 / 2018$, de 31 de enero, el delito de enaltecimiento y justificación del terrorismo del artículo $578 \mathrm{CP}$ requiere "que tal expresión se haga, no para tal expresión emotiva, sino, más allá, para la racional finalidad de procurar que el mensaje, al menos indirectamente, incite a otros a cometer delitos de terrorismo" (F.J.5). En cambio, la STS 72/2018, rescataba la doctrina anterior declarando que "la conducta de enaltecer o justificar el terrorismo del artículo 578 se estructura como una forma autónoma de apología caracterizada por su carácter genérico, sin llegar a integrar una provocación, ni directa ni indirecta del delito" (F.J. Único). 
Sres./Sras. Fiscales tendrán en cuenta las circunstancias concurrentes a fin de valorar si las conductas analizadas en cada caso son susceptibles de generar o no una situación objetiva de peligro o riesgo de que se puedan cometer actos de violencia, hostilidad, discriminación u odio contra un determinado colectivo o una parte o individuo del mismo".

Me parece censurable que una de las máximas instancias jurídico-penales, se aparte de las directrices, tanto de la STC 112/2016, como del TEDH, e inste a los y las Fiscales para que persigan las conductas que puedan propiciar actos de violencia, de discriminación, "de hostilidad", o algo todavía más paradójico, "actos de odio". Además, en este caso resulta difícil discernir a qué sucesos se refiere la Fiscalía, en la medida en que el odio es un sentimiento, y, además, esos actos se mencionan de modo separado de los de violencia, hostilidad y discriminación. Por lo tanto, en lugar de hacer una interpretación restrictiva, requiriendo que el clima pueda concretarse en acciones violentas o delictivas, hace lectura confusa que infringe el principio de taxatividad.

\section{El enaltecimiento de los demás delitos cometidos por motivos discriminatorios}

El artículo 510, apartado 2 b) CP castiga con una pena de prisión de seis meses a dos años y multa de seis a doce meses a quienes enaltezcan o justifiquen por cualquier medio de expresión pública o de difusión los delitos que hubieran sido cometidos contra un grupo, una parte del mismo, o contra una persona determinada por razón de su pertenencia a aquél por motivos racistas, antisemitas u otros referentes a la ideología, religión o creencias, situación familiar, la pertenencia de sus miembros a una etnia, raza o nación, su origen nacional, su sexo, orientación o identidad sexual, por razones de género, enfermedad o discapacidad, o a quienes hayan participado en su ejecución.

El párrafo segundo prevé una disposición aplicable a las conductas del apartado 2 a) y b): "Los hechos serán 
castigados con una pena de prisión de uno a cuatro años de prisión y multa de seis a doce meses cuando de ese modo se promueva o favorezca un clima de violencia, hostilidad, odio o discriminación contra los mencionados grupos".

\subsection{Origen $y$ ratio legis}

En este caso el Anteproyecto ya contemplaba la exigencia de que las expresiones se emitieran por cualquier medio de expresión pública o de difusión ${ }^{94}$. Esta publicidad marcaba la diferencia con las conductas de enaltecimiento y justificación de los delitos de genocidio, de lesa humanidad o contra las personas y bienes protegidos en caso de conflicto armado, para las se añadió después ese elemento. En cambio, en dicho texto no se recogía la agravación del párrafo segundo.

El Consejo General del Poder Judicial señaló que el matiz que diferenciaba este supuesto respecto de la incitación directa o indirecta al odio, hostilidad, discriminación o violencia del artículo 510.1, residía en que el enaltecimiento o justificación no constituían un medio de fomento, incitación o promoción de esos efectos. Pero no denunciaba la insuficiencia de dichas expresiones para constituir delito, puesto que no se precisaba ni siquiera que fomentaran el clima previsto para la negación, apología y trivialización grave de los delitos de genocidio y los demás señalados ${ }^{95}$.

94 Sobre los antecedentes de estos delitos de discriminación a partir de la Ley Orgánica 4/1995, de 11 mayo, puede verse, LANDA GOROSTIZA, J.M.: "El modelo político-criminal antirracista «sui generis» del Código penal español de 1995: una aproximación crítica", en Revue Internationale de Droit Penal. International Review of Penal Law (Revista de la Asociación Internacional de Derecho penal), vol. 73, Association Internationale de Droit Pénal, 2002, pp. 3 y ss; y, TAMARIT SUMALLA, J.M., en QUINTERO OLIVARES, G. (Dir.)/MORALES PRATS, F. (Coord.): Comentarios a la Parte especial del Derecho penal, cit., e-book.

95 Informe del Consejo General del Poder Judicial al Anteproyecto de Ley Orgánica por la que se modifica la Ley Orgánica 10/1995, de 23 de noviembre, del Código Penal, de 16 de enero de 2013, p. 246. 
Por su parte, la Fiscalía General del Estado, apuntó que el artículo 510.2 b) castigaba el enaltecimiento o justificación a posteriori de acciones que persigan las finalidades de odio, e indicaba que se sigue la estela del Derecho alemán, que penaliza dichas conductas en el $\S 130.3$ y 4 StGB. Sin embargo, como se vio, en estas normas se requiere la puesta en peligro o la perturbación de la paz pública ${ }^{96}$. Pese a ello, no cuestionaba la lesividad de esas declaraciones, en las que se omite este presupuesto.

Tampoco el Consejo de Estado puso ningún reparo a este ilícito. Con todo, los defectos observados en otros tipos del artículo 510 le llevaban a recomendar una reconsideración en profundidad de esa norma, atendiendo no solo a la jurisprudencia constitucional y a la mejor incorporación de las previsiones de la Decisión Marco 2008/913/JAI, sino también a la relación entre las conductas contempladas en sus distintos apartados y a la penalidad prevista para cada caso" ${ }^{\prime 97}$.

El tipo cualificado se incorporó en el Proyecto remitido por el Consejo de Ministros al Congreso de los Diputados, en el que se realizó una reestructuración de las conductas. De esta forma, quedaba patente que el tipo básico consistente en el enaltecimiento o justificación de los delitos cometidos frente a los colectivos indicados, no precisaban el riesgo de favorecimiento del clima que daba lugar al delito agravado.

\subsection{Consideraciones críticas}

En esta norma se castiga el enaltecimiento o justificación por un medio de expresión pública o de difusión de

96 Informe del Consejo Fiscal al Anteproyecto de Ley Orgánica por la que se modifica la Ley Orgánica 10/1995, de 23 de noviembre, del Código Penal, de 20 de diciembre de 2012, p. 310.

97 Dictamen del Consejo de Estado sobre el Anteproyecto de ley orgánica por la que se modifica la Ley Orgánica 10/1995, de 23 de noviembre, del Código Penal, de 27 de junio de 2013 (Consideración séptima). 
cualquier delito contra un grupo o sus miembros por motivos discriminatorios. Para completar esta figura no se requiere la creación del clima indicado, que si concurre determina la aplicación de una penalidad igual a la prevista en el artículo 510, apartado 1 c) CP para la negación, trivialización grave y enaltecimiento de los delitos de genocidio, de lesa humanidad o contra las personas y bienes protegidos en caso de conflicto armado.

La incriminación de estas conductas no estaba prevista en la Decisión Marco y se aparta también de la Recomendación de la ECRI de 2015.

Por otra parte, la STC 235/2007 admitió excepcionalmente el castigo de la difusión de ideas que justifiquen el genocidio, atendiendo a la especial peligrosidad de delitos tan odiosos y que ponen en riesgo la esencia misma de nuestra sociedad, cuando tal justificación opere como incitación indirecta a su comisión. Y las SSTC 112/2016 y 35/2020 recogieron esta doctrina para los delitos de enaltecimiento y justificación públicos del terrorismo y de sus autores, a los que el Tribunal Constitucional atribuye igual entidad.

Sin embargo, en este precepto se sanciona el enaltecimiento y la justificación de cualquier delito, como si el sujeto pasivo o el móvil de intolerancia legitimaran la punición de la mera expresión de alabanza o defensa del ilícito que fuere, cuando esas declaraciones no promuevan o favorezcan ningún clima de violencia, hostilidad, odio o discriminación. Además, tampoco han de afectar a la dignidad de las víctimas, porque entonces regiría el artículo 510, apartado 2 a) CP.

Luego, se penaliza la simple expresión de una opinión intolerante, a través del enaltecimiento o justificación de los delitos cometidos por quienes actuaron bajo ese mismo móvil sectario. Y, como ha reiterado el Tribunal Constitucional en nuestro sistema no tiene cabida un modelo de "democracia militante" en el que se exija la asunción de los valores democráticos, de manera que no cabe castigar la mera adhesión 
ideológica a posiciones de cualquier clase, si al defender esas ideas no se afecta a un bien merecedor de la tutela penal. Desde esta perspectiva, me parece que el balance entre el derecho a la no discriminación del artículo $14 \mathrm{CE}$ y el derecho a la libertad de expresión del artículo 20.1 CE ha de ser claramente favorable a este último ${ }^{98}$.

Por lo demás, se aplica la misma pena sea cual sea el delito que se enaltece o justifica, ya se trate de un ilícito contra la libertad sexual, unas lesiones o un delito de discriminación en el empleo, por ejemplo. En cualquier caso, desde el momento en que las expresiones carecen de la lesividad mínima para la intervención penal esta falta de proporcionalidad pierde relevancia.

\section{Conclusiones}

\section{Influencia de la jurisprudencia constitucional sobre enaltecimiento del terrorismo en los tipos de enaltecimiento del artículo 510}

A mi modo de ver, la interpretación que han efectuado las SSTC 112/2016 y 35/2020 de los fundamentos de la STC $235 / 2007$, determinan la lectura que ha de hacerse del artículo 510 , apartados $1 \mathrm{c}$ ) y 2 b) CP.

En esas resoluciones se argumenta que la doctrina sentada en la STC 235/2007 para la difusión de ideas que nieguen o justifiquen el genocidio es aplicable al enaltecimiento y justificación de los delitos de terrorismo y de sus autores del artículo $578.1 \mathrm{CP}$, dada su "similitud estructural" y que son

98 Afirma PORTILLA CONTRERAS que esta figura es "rotundamente inconstitucional", puesto que no respeta el contenido de la Decisión Marco de 2008, ni requiere el elemento adicional exigido en la STC 235/2007 consistente en la presencia de una incitación indirecta, adoptando la excepcionalidad propia del Derecho penal de autor de los artículos 578 y 579 CP. PORTILLA CONTRERAS, G., en QUINTERO OLIVARES, G.: Comentario a la reforma penal de 2015, cit., e-book. 
delitos igualmente odiosos y peligrosos para la esencia misma de nuestra sociedad. Por eso, el legislador puede "excepcionalmente" penalizar esas expresiones, cuando cumplan ciertos presupuestos. Ahora bien, de los distintos fragmentos de la STC 235/2007 que recogen, de forma equívoca, estas exigencias toman aquellos que comportan un sentido más restrictivo de los tipos examinados. Y esta restricción hace cuestionable la adecuación constitucional de aquellas normas del artículo 510.

En efecto, la STC 235/2007 argumentaba, respecto a la difusión de ideas o doctrinas que nieguen los delitos de genocidio tipificada en el artículo 607.2, que el precepto resultaría conforme a la Constitución si se pudiera deducir del mismo que la conducta sancionada implica necesariamente una incitación directa a la violencia contra determinados grupos o un menosprecio hacia las víctimas de los delitos de genocidio.

Menos contundente fue al valorar la siguiente conducta prevista en esa norma, consistente en difundir ideas o doctrinas que justifiquen los delitos de genocidio. En este caso, a mi entender, el Tribunal Constitucional hace afirmaciones confusas respecto a las condiciones para sancionarla.

Señala que "la especial peligrosidad de delitos tan odiosos y que ponen en riesgo la esencia misma de nuestra sociedad permite excepcionalmente que el legislador penal sin quebranto constitucional castigue la justificación pública de ese delito, siempre que tal justificación opere como incitación indirecta a su comisión; esto es incriminándose (y ello es lo que ha de entenderse que realiza el art. $607.2 \mathrm{CP}$ ) conductas que, aunque sea de forma indirecta supongan una provocación al genocidio".

Aquí requiere que la difusión de ideas o doctrinas que justifiquen el genocidio incite indirectamente a ejecutar este delito. Pero a continuación, aparentemente, introduce una segunda posibilidad para castigar esa conducta. 
"Para ello será necesario que la difusión pública de las ideas justificadoras entre en conflicto con bienes constitucionalmente relevantes de especial trascendencia que hayan de protegerse penalmente. Así sucede, en primer lugar, cuando la justificación de tan abominable delito suponga un modo de incitación indirecta a su perpetración. Sucederá también, en segundo lugar, cuando con la conducta consistente en presentar como justo el delito de genocidio se busque alguna suerte de provocación al odio hacia determinados grupos definidos mediante la referencia a su color, raza, religión u origen nacional o étnico, de tal manera que represente un peligro cierto de generar un clima de violencia y hostilidad que puede concretarse en actos específicos de discriminación".

El Tribunal Constitucional ya no exige expresamente que el autor incite indirectamente al genocidio, sino que añade la creación de un clima de violencia u hostilidad que pueda concretarse en actos específicos de discriminación. A su vez, surge la duda de si esos actos de discriminación han de constituir delito, de modo que se sancione, no solo la incitación indirecta al genocidio sino también a otros ilícitos, o si se incluye, incluso, la instigación indirecta a discriminar a las personas de ciertos colectivos a través de hechos no delictivos, como, por ejemplo, negar un puesto de trabajo a un inmigrante. De todos modos, el paralelismo que el Tribunal Constitucional establece con el efecto citado en primer lugar, la incitación indirecta a perpetrar al genocidio, apunta a que efectivamente precisa que la justificación conlleve el riesgo de desencadenar delitos.

Sin embargo, después parece relajar las exigencias anteriores. "De ese modo, resulta constitucionalmente legítimo castigar penalmente conductas que, aun cuando no resulten claramente idóneas para incitar directamente a la comisión de delitos contra el derecho de gentes como el genocidio, sí suponen una incitación indirecta a la misma o provocan de modo mediato a la discriminación, al odio o a la violencia, que 
es precisamente lo que permite en términos constitucionales el establecimiento del tipo de la justificación pública del genocidio". Literalmente parece admitir la provocación indirecta al odio, como efecto condicionante de la constitucionalidad del tipo.

No obstante, creo que este último párrafo es una mera reproducción de la terminología de ciertas normas internacionales, que no anula las exigencias anteriores. Así pues, concluye subrayando que, "esta interpretación constitucionalmente conforme del artículo 607.2 CP en absoluto desvirtúa la voluntad del legislador de sancionar de determinado modo la provocación directa al delito de genocidio (art. $615 \mathrm{CP}$ ), en la medida en que dota al precepto de un ámbito punible propio, que supone en su caso una modalidad específica de incitación al delito que merece por ello una penalidad diferenciada, adaptada, según el criterio del legislador, a la gravedad de dicha conducta conforme a parámetros de proporcionalidad". A diferencia del artículo 615 que regulaba la provocación directa al genocidio, según el Tribunal Constitucional, el artículo 607.2 sancionaba la incitación indirecta a este crimen. Esta conclusión coincide con el requisito que expresaba al principio y que encabezaba la argumentación siguiente.

Precisamente, este entendimiento es el que mantuvieron el ATC 4/2008 y las SSTC 112/2016 y 35/2020, a partir de esta sentencia, requiriendo en el artículo $578.1 \mathrm{CP}$, que el enaltecimiento o la justificación públicos de los delitos de terrorismo o de sus autores inciten indirectamente a la violencia o a realizar esos ilícitos.

En mi opinión, pues, dado que dichas resoluciones aplican el mismo canon de constitucionalidad a la difusión de ideas que justifiquen el genocidio y al enaltecimiento y justificación públicos del terrorismo, para restringir el derecho a la libertad de expresión, ese criterio rige también para el artículo 510, apartado 1 c) CP. De manera que, el enaltecimiento de los delitos de genocidio, lesa humanidad, o contra las 
personas o los bienes protegidos en caso de conflicto armado será punible cuando incite indirectamente a la violencia o al delito. Hay que pensar, además, que esta norma prevé una penalidad mayor que la establecida en el artículo 578.1 CP.

No obstante, como expondré a continuación, a mi juicio, el artículo 510, apartado 1 c) CP admite la incitación a otros ilícitos distintos de los de genocidio, lesa humanidad o contra las personas o los bienes protegidos en caso de conflicto armado recogidos en el precepto.

En cambio, entiendo que las sentencias citadas hacen inviable una interpretación conforme al artículo 20.1 CE, tanto de las demás conductas del artículo 510, apartado $1 \mathrm{c}$ ), como de las del apartado 2 b) CP.

2. El favorecimiento de un «clima» como incitación indirecta a la comisión de otros delitos distintos del genocidio

Tanto la STC 235/2007, como el ATC 4/2008 y las SSTC 112/2016 y 35/2020, precisaban que la justificación del genocidio (antiguo art.607.2), o el enaltecimiento o justificación del terrorismo (art.578.1 CP), incitaran indirectamente a cometer estos mismos delitos, o, según las últimas sentencias a la violencia.

En cambio, el Tribunal Constitucional no se ha pronunciado acerca del artículo $510 \mathrm{CP}$. De modo, que partiendo de la doctrina genérica de aquellas resoluciones cabe plantearse algún aspecto diferencial, en cuanto a los efectos incitadores exigidos.

En efecto, el artículo 510, apartado 1 c) CP precisa que la negación, trivialización grave o el enaltecimiento de los delitos de genocidio, lesa humanidad o contra las personas y bienes protegidos en caso de conflicto armado, o el enaltecimiento de sus autores, promueva o favorezca "un clima de violencia, hostilidad, odio o discriminación" contra los grupos o personas protegidos. 
Por lo tanto, teniendo en cuenta la redacción de esta norma cabe plantearse si es necesaria una incitación indirecta a la ejecución de esos delitos, o si basta la incitación indirecta a otros actos delictivos.

Así pues, en la STC 235/2007 se requirió una instigación indirecta al genocidio. Por su parte, el ATC 4/2008 reprodujo el fundamento de esa sentencia que demandaba "una incitación indirecta a su comisión" -del genocidio-, señalando que esa doctrina es aplicable al enaltecimiento o justificación de los delitos de terrorismo.

En cambio, según las SSTC 112/2016 y 35/2020 las declaraciones han de ser una manifestación del discurso del odio por propiciar o alentar, aunque sea de manera indirecta, una situación de riesgo para las personas o derechos de terceros o para el propio sistema de libertades. Y en la primera esta condición se simplifica diciendo que ha de verificarse si la conducta era una manifestación del discurso del odio, que incitaba a la violencia. Esta referencia a la violencia es lógica respecto a los delitos de terrorismo, que generalmente conllevan su uso.

Sin embargo, en el artículo 510, apartado 1 c) CP se requiere expresamente que la conducta promueva o favorezca un clima de violencia, hostilidad, odio o discriminación y con esta cláusula el legislador no parece requerir que se incite a los propios delitos citados, es decir, al genocidio, delitos contra la humanidad o contra las personas y los bienes protegidos en caso de conflicto armado.

Por otra parte, se trata de una figura dirigida a tutelar el principio de no discriminación y, en definitiva, la dignidad de las víctimas, evitando que sufran acciones ilícitas por motivos de intolerancia, bien por su raza o religión, o por su ideología, creencias, sexo, orientación o identidad sexual, por razones de género, etc. Es evidente que su razón de ser es distinta a la que llevó a tipificar la difusión de ideas que justifiquen el genocidio, del antiguo artículo 607.2 CP, 
pensado para evitar la repetición de acciones genocidas contra los judíos, como de hecho expuso la STC 205/2007, asociando esta norma al Holocausto nazi. Y lo mismo sucede con el castigo del enaltecimiento y justificación del terrorismo del artículo $578.1 \mathrm{CP}$, enfocado a la prevención de estos actos específicos. De manera que el abanico de hechos que quiere evitar aquella norma, es mucho más amplio que el de estas disposiciones.

Por consiguiente, considero que el tipo del artículo 510, apartado 1 c) CP se colma también con la incitación indirecta a realizar otros delitos distintos a los enumerados, que pueden concretarse, por ejemplo, en unas amenazas a las personas de los colectivos afectados.

Esta opción se aparta de la apología del artículo $18 \mathrm{CP}$, que precisa la provocación a un delito concreto, y también de la jurisprudencia constitucional recaída hasta la fecha.

Pero los tipos señalados (art. 607.2 derogado y 578.1 $\mathrm{CP})$, han sido avalados por el Tribunal Constitucional pese a no suponer una provocación directa al delito, como exige el artículo $18 \mathrm{CP}$.

Por otra parte, la redacción del artículo 510, apartado 1 c) $\mathrm{CP}$ es distinta a la de esos preceptos, e incluye expresamente la consecuencia del delito, consistente simplemente en fomentar el clima indicado.

Por consiguiente, entiendo que, en este caso, partiendo del canon de constitucionalidad fijado en aquellas resoluciones, es necesario que el enaltecimiento conlleve una incitación indirecta a realizar actos delictivos contra los colectivos y personas tutelados, pero estos ilícitos pueden consistir en hechos distintos a los enumerados, de genocidio, lesa humanidad o contra las personas y los bienes protegidos en caso de conflicto armado. En definitiva, se trata de fomentar actuaciones delictivas contra los grupos discriminados a través del enaltecimiento de los delitos citados. 
Esta fórmula es la que recogen las normas europeas señaladas, tanto la Recomendación No R (97) del Consejo de Europa, como la Recomendación General $N^{\circ} 15$ de la ECRI de 2015, y es también la que mantiene en la praxis el TEDH.

3. Propuestas de lege ferenda. Supresión de las expresiones que no conllevan una incitación al delito

En mi opinión, las conductas de enaltecimiento deberían sancionarse solo cuando provoquen directamente a cometer un delito, en sintonía con el artículo 18 CP. Como ha señalado el Tribunal Constitucional, "al resguardo de la libertad de opinión cabe cualquiera, por equivocada o peligrosa que pueda parecer..., incluso las que ataquen al propio sistema democrático. La Constitución -se ha dicho-protege también a quienes la niegan"99.

No obstante, si como dice el propio Tribunal, en el caso de los delitos de genocidio y de terrorismo, por su carácter odioso y peligroso para la esencia misma de la sociedad, cabe "excepcionalmente" castigar el enaltecimiento y justificación de esos ilícitos, el legislador está legitimado, como ha hecho, para tipificar estas expresiones.

Ahora bien, el Tribunal ha determinado que esas conductas solo podrán castigarse penalmente cuando supongan una incitación, al menos indirecta, a cometer delitos.

Pero como se desprende de las sentencias citadas, la negación pública del genocidio no conlleva ese carácter incitador, por lo que, a mi juicio, debería eliminarse del artículo 510 , apartado $1 \mathrm{c}$ ) $\mathrm{CP}$, al igual que la trivialización grave de los delitos enumerados.

Asimismo, entiendo que también el artículo 510, apartado 2 b) CP tendría que derogarse.

En esta norma se castiga a quienes enaltezcan o justifiquen por cualquier medio de expresión pública o de difusión

99 STC 214/1991, de 11 de noviembre (F.J.8). 
los delitos cometidos contra un grupo o las personas pertenecientes al mismo, por causas de intolerancia.

Por lo tanto, se criminaliza el enaltecimiento o justificación de cualquier delito realizado contra esos colectivos o sus miembros. No se ciñe la punición a los crímenes para los que el Tribunal permite "excepcionalmente" penalizar esas expresiones, por su naturaleza odiosa y peligrosa, es decir, a los de genocidio y terrorismo.

Además, se castiga con igual pena el enaltecimiento y justificación de cualquier delito, con independencia de su gravedad, ya sea de lesiones, amenazas, contra la libertad sexual, o de discriminación en el empleo, por poner algunos ejemplos.

Pero lo que es más importante, en el artículo 510, apartado 2 b) CP el tipo básico se completa con el mero enaltecimiento o justificación, sin requerir la creación de un clima de violencia, hostilidad, odio o discriminación, como en el artículo 510, apartado 1 c) CP, que si concurre da lugar al delito agravado del párrafo segundo.

Por consiguiente, no es necesario el efecto incitador, ni siquiera indirecto, que en todo caso ha establecido como requisito imprescindible el Tribunal Constitucional para castigar las conductas de enaltecimiento o justificación.

En definitiva, se sanciona la pura exposición de una opinión, moralmente repudiable sin lugar a dudas por su cariz sectario, pero que a mi juicio está claramente cubierta por el artículo 20.1 CE. Por eso, entiendo que con su redacción actual no superaría el "test" de constitucionalidad si se sometiera al control del Tribunal Constitucional y, en consecuencia, debería despenalizarse. 


\section{Bibliografía}

ALASTUEY DOBÓN, C., "La reforma de los delitos de provocación al odio y justificación del genocidio en el Proyecto de Ley de 2013: consideraciones críticas (1)", en Diario La Ley, $\mathrm{n}^{\circ}$ 8245, 2014.

ALASTUEY DOBÓN, C., "Discurso del odio y negacionismo en la reforma del Código penal de 2015", en Revista Electrónica de Ciencia Penal y Criminología, 18-14, 2016.

ALCÁCER GUIRAO, R., "Discurso del odio y discurso político. En defensa de las libertades de los intolerantes", en Revista Electrónica de Ciencia Penal y Criminología, 14-02, 2012. (Disponible en: http://criminet.ugr. es/recpc).

ÁLVAREZ GARCÍA, F. J., "La nueva reforma penal de 2013", en Eunomía. Revista en Cultura de la Legalidad, no 6, 2014.

BERNAL DEL CASTILLO, J., "El enaltecimiento del terrorismo y la humillación a sus víctimas como formas del «discurso del odio»", en Revista de Derecho Penal y Criminología, $\mathrm{n}^{\circ}$ 16, 2018.

BILBAO UBILLOS, J.M., "La negación del Holocausto en la jurisprudencia del Tribunal Europeo de Derechos Humanos: la endeble justificación de tipos penales contrarios a la libertad de expresión", en Revista de Derecho Político, $\mathrm{n}^{\circ}$ 71-72, 2008. (Disponible en: https://doi.org/10.5944/rdp.71-72.2008.9038).

BORJA JIMÉNEZ, E., "Presupuestos político-criminales del nacimiento de la legislación penal contra el racismo y la xenofobia en Europa", en GARCÍA AÑóN, J./RUIZ SANZ, M.: Discriminación racial y étnica, Publicaciones de la Universitat de València, 2013.

CAMARERO GONZÁLEZ, G., en GARCÍA, A. (Dir.)/ESCOBAR JIMÉNEZ, R. (Coord.), Código penal. Comentario y jurisprudencia, Comares, Granada, 2018. 
CAMPOS MORENO, J. C., "Actos preparatorios punibles", en Cuadernos de Derecho Judicial, vol. 39, 1994.

CANCIO MELIÁ, M., Los delitos de terrorismo: estructura típica e injusto, Reus, Madrid, 2010.

CARBONELL MATEU, J. C., "Las libertades de información y expresión como objeto de tutela y como límites a la actuación del Derecho penal", en EStudios Penales y Criminológicos, $\mathrm{n}^{\circ}$ 18, 1994-1995. (Disponible en: https://dialnet.unirioja.es/servlet/ articulo? codigo $=2104173$ ).

CARBONELL MATEU, J. C., "Crítica a los sentimientos como bien jurídico-penal", en Liber Amicorum. Estudios Jurídicos en Homenaje al Prof. Dr. Dr. H.c. Juan $M^{a}$ Terradillos Basoco, Tirant lo Blanch, Valencia, 2018.

COMAS DE ARGEMIR CENDRA, M., "Evolución jurisprudencial en los delitos relacionados con el discurso del odio punible: los límites de la libertad de expresión", en Cuadernos Digitales de Formación, Consejo General del Poder Judicial, nº 9, 2017.

CORCOY BIDASOLO, M./MIR PUIG, S., Comentarios al Código penal. Reforma LO 1/2015 y LO 2/2015, Tirant lo Blanch, Valencia, 2015.

CÓRDOBA RODA, J./GARCÍA ARÁN, M., Comentarios al Código penal. Parte general, Marcial Pons, Madrid, 2011.

CORRECHER MIRA, J., ¿¿Fin de la broma? El caso Strawberry y el canon constitucional sobre libertad de expresión aplicado al enaltecimiento del terrorismo (1)", en Diario La Ley, n ${ }^{\circ}$ 9600, 24 de marzo de 2020.

CUERDA ARNAU, M. L., "El denominado delito de apología del genocidio. Consideraciones constitucionales", en Poder Judicial, n 56, 1999.

CUERDA ARNAU, M. L., "El nuevo delito político: apología, enaltecimiento y opinión", en Estudios de Derecho Judicial, nº 128, 2007. 
CUERDA ARNAU, M. L., "Proporcionalidad penal y libertad de expresión: la función dogmática del efecto desaliento", en Revista General de Derecho Penal, n ${ }^{\circ}$ 8, 2007.

CUERDA ARNAU, M. L., "Terrorismo y libertades políticas", en Teoría \& Derecho: Revista de Pensamiento Jurídico, $\mathrm{n}^{\circ}$ 3, 2008.

CUERDA ARNAU, M. L., "Libertad de expresión y crítica política a la luz de la jurisprudencia del TEDH", en Teoría \& Derecho: Revista de Pensamiento Jurídico, $\mathrm{n}^{\circ}$ 13, 2013.

CUERDA ARNAU, M. L., en GONZÁLEZ CUSSAC, J.L: (Coord.), Derecho penal. Parte especial, $6^{\text {a }}$ edición, Tirant lo Blanch, Valencia, 2019.

DEL ROSAL BLASCO, B., en MORILLAS CUEVA, L. (Dir.), Sistema de Derecho penal. Parte especial, $2^{\mathrm{a}}$ edición, Dykinson, Madrid, 2016.

DÍAZ Y GARCÍA CONLLEDO, M., "El discurso de odio y el delito de odio de los arts. 510 y 510 bis del Código Penal: Necesidad de limitar", Límites a la libertad de expresión, en Boletín Juezas y Jueces para la Democracia, mayo de 2018.

DOPICO, J., "Desconciertos de Brandemburgo", Límites a la libertad de expresión, en Boletín Juezas y Jueces para la Democracia, mayo de 2018.

ELÓSEGUI ITXASO, M., "La negación o justificación del genocidio como delito en el derecho europeo. Una propuesta a la luz de la Recomendación n ${ }^{\circ} 15$ de la ECRI", en Revista de Derecho Político, $\mathrm{n}^{\circ}$ 8, 2017. (Disponible en: https://doi.org/10.5944/rdp.98.2017.18657).

FUENTES OSORIO, J. L, "El odio como delito", en Revista Electrónica de Derecho Penal y Criminología, 19-27, 2017.

GALÁN MUÑOZ, A., "El delito de enaltecimiento terrorista. ¿Elemento de lucha contra el peligroso discurso del odio terrorista o mecanismo represor de repudiables 
mensajes de raperos, twitteros y titiriteros?", en Estudios Penales y Criminológicos, vol. XXXVII, 2018. (Disponible en: https://doi.org/10.15304/epc.38.5127).

GARCÍA ARÁN, M., "De las reformas bienintencionadas con resultados represivos: el delito de promoción del odio", en MORALES PRATS, F./TAMARIT SUMALLA, J.M./GARCÍA ALBERO, R. (Coord.): Represión penal y Estado de Derecho. Homenaje al Profesor Gonzalo Quintero Olivares, Aranzadi, Pamplona, 2018. GARCÍA ÁlVAREZ, P., El Derecho penal y la discriminación, Tirant lo Blanch, Valencia, 2004.

GARROCHO SALCEDO, A./PORTILLA CONTRERAS, G., "Delitos de incitación al odio, la hostilidad, la discriminación o la violencia", en ÁLVAREZ GARCÍA, F. J. (Dir.)/DOPICO GÓMEZ-ALLER, J. (Coord.), Estudio crítico sobre el Anteproyecto de reforma penal de 2012, Tirant lo Blanch, Valencia, 2013.

GÓMEZ MARTÍN, V.: "Discurso del odio y principio del hecho", en MIR PUIG, S./CORCOY BIDASOLO, M. (Dir.), Protección penal de la libertad de expresión e información. Una interpretación constitucional, Tirant lo Blanch, Valencia, 2012.

GÓMEZ MARTÍN, V., "Fighting words, Auschwitzlüge y libertad de expresión", en InterseXiones 4, 2013.

GÓMEZ MARTÍN, V., en CORCOY BIDASOLO, M./MIR PUIG, S. (Dir.): Comentarios al Código penal, Tirant lo Blanch, Valencia, 2015.

GÓMEZ MARTÍN, V., Delitos de discriminación y discurso del odio punible. Nuevo escenario en España tras la LO 1/2015, Juruá Editorial, Portugal, 2019.

HORMAZÁBAL MALAREÉ, H.: "Soberanía y responsabilidad internacional", en CARBONELL, J.C.I GONZÁLEZ CUSSAC, J.L./ORTS BERENGUER, E. (Dir.)/CUERDA ARNAU, M.L. (Coord.), Constitución, derechos fundamentales y sistema penal, Tomo II, Tirant lo Blanch, Valencia, 2009. 
HÖRNLE, T.: "La protección de sentimientos en el StGB", en HEFENDEHL, R. (Ed.), La teoría del bien jurídico. ¿Fundamento de legitimación del Derecho penal o juego de abalorios dogmáticos?, Marcial Pons, Madrid, 2007.

LAMARCA PÉREZ, C., en LAMARCA PÉREZ, C. (Coord.), Delitos. La parte especial del Derecho penal, $2^{\mathrm{a}}$ edición, Dykinson, Madrid, 2017.

LANDA GOROSTIZA, J. M., "La llamada «mentira de Auschwitz» (art. 607-2 ${ }^{\circ} \mathrm{CP}$ ) y el «delito de Provocación» (art. $510 \mathrm{CP}$ ) a la luz del «caso Varela»: una oportunidad perdida para la «cuestión de inconstitucionalidad» (Comentario a la Sentencia del Juzgado de lo penal $\mathrm{N}^{\mathrm{o}} 3$ de Barcelona de 16 de noviembre de 1998)", en Actualidad Penal, 1999.

LANDA GOROSTIZA, J. M., La política criminal contra la xenofobia y las tendencias expansionistas del Derecho penal, Comares, Granada, 2001.

LANDA GOROSTIZA, J. M., "El modelo político-criminal antirracista «sui generis» del Código penal español de 1995: una aproximación crítica", en Revue Internationale de Droit Penal. International Review of Penal Law. (Revista de la Asociación Internacional de Derecho penal), vol. 73, Association Internationale de Droit Pénal, 2002.

LANDA GOROSTIZA, J. M., "Incitación al odio: evolución jurisprudencial (1995-2011) del art. 510 CP y propuesta de lege lata", en Revista de Derecho Penal y Criminología, $\mathrm{n}^{\circ}$ 7, 2012.

LANDA GOROSTIZA, J. M., Los delitos de odio, Tirant lo Blanch, Valencia, 2018.

LASCURAÍN SÁNCHEZ, J.A., "La libertad de expresión tenía un precio. (Sobre la STC 235/2007, de inconstitucionalidad del delito de negación del genocidio)", en Revista Aranzadi Doctrinal, nº 6, 2010. 
LAURENZO COPELLO, P., "Marco de protección jurídico penal del derecho a no ser discriminado. Racismo y xenofobia”, en MAQUEDA ABREU, M.L. (Dir.), Libertad ideológica y derecho a no ser discriminado, en Cuadernos de Derecho Judicial, 1996.

LAURENZO COPELLO, P., "Sentimientos religiosos y delitos de odio: un nuevo escenario para unos delitos olvidados", en Liber Amicorum. Estudios Jurídicos en Homenaje al Prof. Dr. Dr. H.c. Juan $M^{a}$ Terradillos Basoco, Tirant lo Blanch, Valencia, 2018.

LAURENZO COPELLO, P., "La protección penal frente a las conductas racistas y xenófobas", en SOROETA LICERAS, J. (Ed.), Cursos de Derechos Humanos de Donostia-San Sebastián, vol. II, Universidad del País Vasco, 1999-2000.

LAURENZO COPELLO, P., "La manipulación de los delitos de odio", en PORTILLA CONTRERAS, G./ VELÁSQUEZ VELÁSQUEZ, F. (Dir.)/POMARES CINTAS, E./FUENTES OSORIO, J.L. (Coord.), Un juez para la democracia. Libro Homenaje a Perfecto Agustín Andrés Ibáñez, Dykinson, Madrid, 2020.

LEÓN ALAPONT, J., "Defensa de regímenes totalitarios: aspiraciones punitivas en tiempos democráticos", en Diario La ley, $\mathrm{n}^{\circ}$ 9572, 12 de febrero de 2020.

MAQUEDA ABREU, M. L., "Algunas reflexiones críticas acerca de la punición de la apología", en Revista del Poder Judicial, nº 9, 1988.

MOLINA BLÁZQUEZ, M. C., "Valoración crítica de la Circular 7/2019 de la Fiscalía General del Estado sobre las pautas para interpretar los delitos de odio del art. 510 del Código penal”, en GUZMÁN ORDAZ, R. (Coord.)/GORJÓN BARRANCO, M.C. (Dir.), Políticas públicas en defensa de la inclusión, la diversidad y el género, Universidad de Salamanca, 2020.

MARTÍNEZ SOSPEDRA, M., "Aplastar a una serpiente en el huevo. Acerca de la cuestión de inconstitucionalidad 
promovida contra el artículo 607.2 del CP”, en Revista General de Derecho, $\mathrm{n}^{\circ}$ 664-665, 2000.

MIRA BENAVENT, J, "El delito de enaltecimiento del terrorismo, el de humillación a las víctimas del terrorismo y la competencia de la Audiencia Nacional: ni delito, ni terrorismo, ni competencia de la Audiencia Nacional", en ALONSO RIMO, A./CUERDA ARNAU, M.L./FERNÁNDEZ HERNÁNDEZ, A. (Dir.), Terrorismo, sistema penal y derechos fundamentales, Tirant lo Blanch, Valencia, 2018.

MORALES PRATS, F., en QUINTERO OLIVARES, G. (Dir.)/ MORALES PRATS, F. (Coord.), Comentarios al Código penal español, Tomo I, Aranzadi, Pamplona, 2016.

MORENO HUERTA, J. D., "Análisis del nuevo delito de adoctrinamiento del artículo 575.2 del Código penal incorporado con la Ley Orgánica 2/2015 (1)", en Anuario de Derecho Penal y Ciencias Penales, vol. LXX, 2017.

MUÑOZ CONDE, F., Derecho penal. Parte especial, $20^{\mathrm{a}}$ edición, Tirant lo Blanch, Valencia, 2015.

ORTS BERENGUER, E., "Consideraciones sobre la fase interna y los actos preparatorios del delito", en Cuadernos de Política Criminal, $\mathrm{n}^{\circ}$ 18, 1982.

ORTS BERENGUER, E./GONZÁLEZ CUSSAC, J. L., Compendio de Derecho penal. Parte general, Tirant lo Blanch, Valencia, 2019. (Disponible en: https://doi. org/10.22518/20271743.302).

PORTILLA CONTRERAS, G., en QUINTERO OLIVARES, G., Comentario a la reforma penal de 2015, Aranzadi, Pamplona, 2015, e-book.

PORTILLA CONTRERAS, G., "La represión penal del «Discurso del odio»", en QUINTERO OLIVARES, G. (Dir.), Comentarios a la reforma penal de 2015, Aranzadi, Pamplona, 2015.

REBOLLO VARGAS, R, La provocación y la apología en el nuevo Código penal, Tirant lo Blanch, Valencia, 1997. 
REVENGA SÁNCHEZ, M., "Los discursos del odio y la democracia adjetivada: tolerante, intransigente, ¿militante?", en REVENGA SÁNCHEZ, M. (Dir.), Libertad de expresión y discursos del odio, Universidad de Alcalá, 2015.

RODRÍGUEZ PADRÓN, C., "Delitos de odio", en Cuadernos Digitales de Formación, Consejo General del Poder Judicial, nº 39, 2018.

ROIG TORRES, M., "Los delitos de racismo y discriminación (arts. 510, 510 bis, 511 y 512), en GONZÁLEZ CUSSAC, J.L. (Dir.)/GÓRRIZ ROYO, E./MATALLÍN EVANGELIO, Á. (Coord.), Comentarios a la reforma del código penal de $2015,2^{\mathrm{a}}$ edición, Tirant lo Blanch, Valencia, 2015.

ROIG TORRES, M., Delimitación entre libertad de expresión $y$ «discurso del odio». Postura del TEDH, del Tribunal Constitucional español y del Tribunal Constitucional alemán, Tirant lo Blanch, Valencia, 2020.

ROSENFELD, M., "Hate speech in constitutional jurisprudence: a comparative analysis", en Cardozo Law School, $\mathrm{n}^{\mathrm{o}}$ 41, 2001. (Disponible en: https://doi. org/10.2139/ssrn.265939).

ROXÍN, C., “¿Es la protección de bienes jurídicos una finalidad del Derecho penal?", en HEFENDEHL, R. (Ed.), La teoría del bien jurídico. ¿Fundamento de legitimación del Derecho penal o juego de abalorios dogmáticos?, Marcial Pons, Madrid, 2007.

SÁEZ VALCÁRCEL, R., "La libertad de expresión", Límites a la libertad de expresión, en Boletín Juezas y Jueces para la Democracia, mayo de 2018.

SÁEZ VALCÁRCEL, R., "Apología del terrorismo, libertad de expresión y libertad de creación artística. La criminalización del arte, la ficción y la caricatura", en Cuadernos Digitales de Formación, Consejo General del Poder Judicial, nº 40, 2019. 
SAINZ-DÍEZ DE ULZURRUN LLUCH, M., "El peligro de las palabras. A propósito del delito de apología del genocidio", en CUERDA RIEZU, A./JIMÉNEZ GARCÍA, F. (Dir.), Nuevos desafios del Derecho penal internacional, Tecnos, Madrid, 2009.

STERNBERG-LIEBEN/SCHITTENHELM, en SCHÖNKE, A./SCHRÖDER, H., Strafgesetzbuch Kommentar, 30 Auflage, Verlag. C.H.Beck München, 2019.

TAMARIT SUMALLA, J. M., en QUINTERO OLIVARES, G. (Dir.)/MORALES PRATS, F. (Coord.), Comentarios a la Parte especial del Derecho penal, $10^{\mathrm{a}}$ edición, Aranzadi, 2016, e-book.

TAMARIT SUMALLA, J. M., "Los delitos de odio en las redes sociales", en Revista de Internet, Derecho y Politi$c a, \mathrm{n}^{\circ} 27,2018$. (Disponible en: https://idp.uoc.edu/articles/10.7238/idp.v0i27.3151/galley/3491/download/).

TAPIA BALLESTEROS, P., en GÓMEZ TOMILLO, M./JAVATO MARTÍN, A.M. (Dir.), Comentarios prácticos al Código penal, Tomo VI, Aranzadi, Pamplona, 2015.

TERUEL LOZANO, G. M., "Expresiones intolerantes, delitos de odio y libertad de expresión: un difícil equilibrio", en Revista Jurídica de la Universidad Autónoma de Madrid, n. ${ }^{\circ}$ 36, 2017-II.

VALLS PRIETO, J., en MORILLAS CUEVA (Dir.), Estudios sobre el Código penal reformado, Dykinson, Madrid, 2015.

VIVES ANTÓN, T. S., Libertad de prensa y responsabilidad criminal. (La regulación de la autoría en los delitos cometidos por medio de imprenta), vol. 14, Publicaciones del Instituto de Criminología de la Universidad Complutense de Madrid, 1977.

VIVES ANTÓN, T. S., La libertad como pretexto, Tirant lo Blanch, Valencia, 1995.

VIVES ANTÓN, T. S., en VIVES ANTÓN, T.S. (Coord.): Comentarios al Código penal de 1995, vol. I, Tirant lo Blanch, Valencia, 1996. 
VIVES ANTÓN, T. S., "Sistema democrático y concepciones del bien jurídico: el problema de la apología del terrorismo", en Estudios Penales y Criminológicos, vol. XXV, 2005.

VIVES ANTÓN, T. S., "Sistema democrático y concepciones del bien jurídico: el problema de la apología del terrorismo", en GÓMEZ COLOMER, J. L./GONZÁLEZ CUSSAC, J. L. (Dir.), Terrorismo y proceso penal acusatorio, Tirant lo Blanch, Valencia, 2006.

VIVES ANTÓN, T. S., "Sobre la apología del terrorismo como "discurso" del odio", en REVENGA SÁNCHEZ, M. (Dir.): Libertad de expresión y discursos del odio, Universidad de Alcalá, 2015.

VIVES ANTÓN, T. S., en GONZÁLEZ CUSSAC, J. L: (Coord.): Derecho penal. Parte especial, $6^{\mathrm{a}}$ edición, Tirant lo Blanch, Valencia, 2019.

VIVES ANTÓN, T. S., "Sobre la apología del terrorismo como discurso del odio", en VIVES ANTÓN, T.S.: Pensar la libertad. Últimas reflexiones sobre el Derecho y la justicia, Tirant lo Blanch, Valencia, 2019. 